\title{
Timing of magmatic-hydrothermal activity in the Variscan Orogenic Belt: LA-ICP-MS U-Pb geochronology of skarn-related garnet from the Schwarzenberg District, Erzgebirge
}

\author{
Nils Reinhardt ${ }^{1} \cdot$ Axel Gerdes $^{2,3} \cdot$ Aratz Beranoaguirre $^{2,3,4} \cdot$ Max Frenzel $^{5} \cdot$ Lawrence D. Meinert $^{6} \cdot$ Jens $^{\text {Gutzmer }}$ Man $^{1,5}$. \\ Mathias Burisch ${ }^{1,5}$
}

Received: 26 February 2021 / Accepted: 13 November 2021 / Published online: 11 January 2022

(c) The Author(s) 2022

\begin{abstract}
Here, we present in situ U-Pb laser ablation-inductively coupled plasma-mass spectrometry (LA-ICP-MS) ages of andraditegrossular garnet from four magmatic-hydrothermal polymetallic skarn prospects in the Schwarzenberg District, Erzgebirge (Germany), located in the internal zone of the Variscan Orogenic Belt. Within the geochronological framework of igneous rocks and hydrothermal mineralization in the Erzgebirge, the obtained garnet ages define three distinct episodes of Variscan skarn formation: (I) early late-collisional mineralization (338-331 Ma) recording the onset of magmatic-hydrothermal fluid flow shortly after the peak metamorphic event, (II) late-collisional mineralization ( 327-310 Ma) related to the emplacement of large peraluminous granites following large-scale extension caused by orogenic collapse and (III) post-collisional mineralization ( 310-295 Ma) contemporaneous with widespread volcanism associated with Permian crustal reorganization. Our results demonstrate that the formation of skarns in the Schwarzenberg District occurred episodically in all sub-stages of the Variscan orogenic cycle over a time range of at least $40 \mathrm{Ma}$. This observation is consistent with the age range of available geochronological data related to magmatic-hydrothermal ore deposits from other internal zones of the Variscan Orogenic Belt in central and western Europe. In analogy to the time-space relationship of major porphyry-Cu belts in South America, the congruent magmatic-hydrothermal evolution in the internal zones and the distinctly later (by $30 \mathrm{Ma}$ ) occurrence of magmatic-hydrothermal ore deposits in the external zones of the Variscan Orogenic Belt may be interpreted as a function of their tectonic position relative to the Variscan collisional front.
\end{abstract}

Keywords U-Pb LA-ICP-MS garnet geochronology · Skarn · Tin-tungsten deposits · Magmatic-hydrothermal · Variscan orogeny $\cdot$ Erzgebirge

\section{Introduction}

Tin and W deposits are commonly associated with highly evolved ilmenite-series (peraluminous) granitoid rocks in collisional zones (Lehmann 2020); they occur in a number

Editorial handling: J. Mercadier

Nils Reinhardt

nils.reinhardt@mineral.tu-freiberg.de

Mathias Burisch

mathias.burisch@mineral.tu-freiberg.de

1 Institute of Mineralogy, TU Bergakademie Freiberg, 09599 Freiberg, Germany

2 Frankfurt Isotope and Element Research Center (FIERCE), Goethe University Frankfurt, 60438 Frankfurt/Main, Germany
3 Department of Geosciences, Goethe University Frankfurt, 60438 Frankfurt/Main, Germany

4 Department of Geology, University of the Basque Country UPV/EHU, 48940 Leioa, Spain

5 Helmholtz-Zentrum Dresden-Rossendorf, Helmholtz Institute Freiberg for Resource Technology, 09599 Freiberg, Germany

6 Department of Geology and Geological Engineering, Colorado School of Mines, Golden, CO 80401, USA 
of mineralization styles, including vein-type, skarn, carbonate replacement, and greisen deposits. Major Sn-W ore provinces include the Bolivian Sn belt, the Southeast Asian Sn belt, the Western Tasmanian Sn province, and also the Acadian-Variscan-Appalachian Sn-W belt of northeast America and Europe (Hong et al. 2017; Richards 2011; Romer and Kroner 2016). The timing of Sn and $\mathrm{W}$ mineralization within the orogenic cycle, however, remains insufficiently understood in many cases. The internal zones of the Variscan Orogenic Belt of central and western Europe are an excellent example as they are host to several prolific Sn-W provinces. It has been widely assumed that formation of magmatic-hydrothermal ore deposits in these provinces is constrained to a narrow interval of $\leq 15 \mathrm{Ma}$ (e.g., Bouchot et al. 2005; Cuney et al. 2002; Lefebvre et al. 2019; Romer et al. 2007; Zhang et al. 2017) coinciding with intense magmatism during post-collisional extension (Förster et al. 1999). This is in contrast to several recent studies suggesting that magmatic-hydrothermal Sn-W-polymetallic mineralization formed episodically over a time span of more than $40 \mathrm{Ma}$ (Burisch et al. 2019b; Harlaux et al. 2018; Moscati and Neymark 2020; Romer and Kroner 2015, 2016; TimónSánchez et al. 2019; Zhang et al. 2019).

These contrasting views on the timing and intervals in which magmatic-hydrothermal systems develop in collisional zones can mainly be attributed to the challenges associated with the direct dating of hydrothermal mineralization; greisen, skarn, and vein-type mineralization does not generally contain minerals suitable for conventional isotope geochronology. Furthermore, extensive hydrothermal overprinting may lead to systematic underestimation of the age of ore formation.

Recent advances in U-Pb LA-ICP-MS geochronology of carbonates (Burisch et al. 2017, 2018; Roberts et al. 2020), cassiterite (Yuan et al. 2011; Zhang et al. 2017), and garnet (Burisch et al. 2019b; Deng et al. 2017; Gevedon et al. 2018; Seman et al. 2017; Wafforn et al. 2018) provide a time- and cost-efficient toolkit to age-date hydrothermal mineralization. Garnet in particular is an ubiquitous skarn mineral, usually occurring early in the paragenetic sequence (Meinert et al. 2005). Garnet crystallization, hence, can be assumed to capture the onset of hydrothermal activity. This information may be used to correlate skarn formation with geodynamic processes, such as discrete magmatic-hydrothermal events. Despite the increasing number of studies that apply U-Pb LA-ICP-MS garnet dating, the precise mechanism of $\mathrm{U}$ incorporation into andradite-grossular garnet (grandite) still remains insufficiently constrained (cf. Guo et al. 2016; Rák et al. 2011; Smith et al. 2004). However, andradite-rich zones in grandite tend to be favorable for U-Pb LA-ICP-MS geochronology (cf. Gevedon et al. 2018; Seman et al. 2017; Wafforn et al. 2018), which may be attributed to a coupled substitution mechanism promoting the incorporation of $\mathrm{U}$ into andradite (Rák et al. 2011).

In this contribution, we present in situ U-Pb LA-ICPMS geochronological data of andradite-grossular garnet from four major skarn prospects in the Schwarzenberg District, Erzgebirge (Germany). Complemented with published geochronological data, the timing and episodes in which magmatic-hydrothermal activity in the Erzgebirge occurred is constrained. Results are matched and critically evaluated together with available age data for magmatic-hydrothermal $\mathrm{Sn}$ and $\mathrm{W}$ mineralization in other parts of the internal (and external) zones of the Variscan Orogenic Belt.

\section{Geological setting}

\section{The European Variscides}

The Variscan Orogenic Belt in Europe is part of the AcadianVariscan-Appalachian belt of northeast America and Europe. The closure of the Rheic ocean and subsequent continental collision of Gondwana and Laurussia from 390 to $330 \mathrm{Ma}$ (Kroner et al. 2008) was followed by post-kinematic extension and crustal reorganization from 330 to $280 \mathrm{Ma}$ (Dias et al. 1998; Kroner and Romer 2013). The external zones of the European Variscan Belt (e.g., Rhenohercynian Zone, Cornwall, Cantabrian Zone, South Portuguese Zone) form an extensive fold-and-thrust belt of Palaeozoic low-grade (meta-)sedimentary rocks. In contrast, the internal zones (e.g., Central Iberian Zone, Amorican Massif, French Massif Central, Moldanubian Zone, Saxothuringian Zone) are characterized by the juxtaposition of low- and high-strain domains and regional low- to high-grade metamorphism (Dallmeyer et al. 1997; Faure et al. 2009; Kroner et al. 2008; Kroner and Romer 2013).

Magmatic activity is documented throughout the entire orogenic cycle of the Variscan Orogenic Belt, but is especially prominent during the late- to post-collisional stages (330 to $280 \mathrm{Ma}$ ), forming mostly ilmenite-series granitoid intrusions (e.g., Dias et al. 1998, 2002; Finger et al. 1997; Förster et al. 1999; Kroner and Romer 2013). Tin-W-polymetallic greisen, skarn, and vein-type mineralization in the internal and external zones of the European Variscan Belt is vaguely constrained to intervals from $~ 335$ to 310 and 300 to 275 Ma related to late- and post-collisional magmatism, respectively (Romer and Kroner 2015, 2016 and reference therein). This includes the economically most significant $\mathrm{Sn}-\mathrm{W}$ provinces, e.g., Cornwall, the Iberian Massif, and the Erzgebirge (Elsner 2014), but almost certainly also Europe's largest operating tungsten mine, the Felbertal deposit in Austria (Kozlik et al. 2016). However, the precise timing of Sn-W-polymetallic ore formation remains rather poorly constrained for most of the districts. 


\section{The Erzgebirge}

The Erzgebirge/Krušné hory Province is an erosional window stretching northeast-southwest over $\sim 145 \mathrm{~km}$ along the northern margin of the Bohemian Massif. Located in the Saxothuringian Zone, it forms part of the internal zone of the European Variscan Belt (Fig. 1a; Kroner et al. 2008;
Romer and Kroner 2015). It is predominantly composed of high-grade gneisses in the east and southeast of the province, whereas low- to medium-grade mica schists, metacarbonates, metavolcanics, phyllites, and quartzites dominate the western and northwestern section with peak metamorphic conditions reached at $340 \mathrm{Ma}$ (Kröner and Willner 1998). Following rapid exhumation and erosion (Kröner and
Fig. 1 A Schematic map of the Variscan Orogenic Belt in western and central Europe (modified from Harlaux et al. 2018). Symbols mark the location of significant Sn-W deposits in the internal and external zones of the European Variscan Belt. Study area marked by red square (not to scale). B Simplified geological map of the Schwarzenberg District (modified from GeoSN 2020, with additional information from Anglo Saxony Mining Ltd. 2020 and Schuppan and Hiller 2012). Shaded areas mark the extent of mineralized skarn bodies as a surface projection. Stars indicate sample localities for this study. Garnet $\mathrm{U}-\mathrm{Pb}$ LA-ICP-MS ages are provided as black boxes (this study) and red boxes (Burisch et al. 2019b) for each skarn. Reference coordinate system is ETRS89 UTM zone 33N. C: Cornwall; AM: Armorican Massif; RHZ: Rhenohercynian Zone; STZ: Saxothuringian Zone; MZ: Moldanubian Zone; ERZ: Erzgebirge; BM: Bohemian Massif; FMC: French Massif Central; IM:, Iberian Massif; ASGS: Aue-Schwarzenberg granite suite; EIB: Eibenstock granite; GER: Germany; CZ: Czech Republic

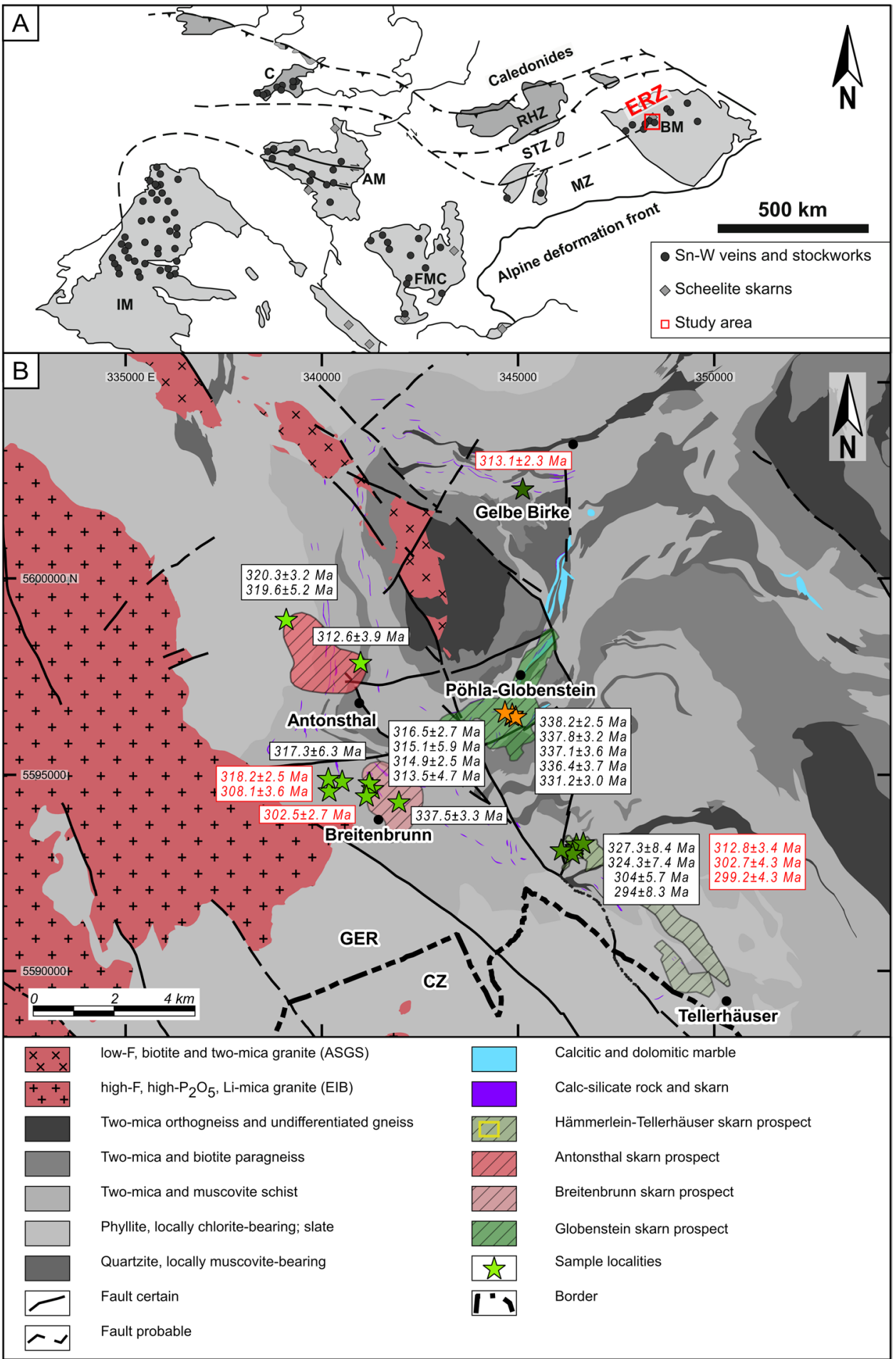


Willner 1998; Schmädicke et al. 1995), the metamorphic basement was intruded by voluminous late-collisional peraluminous granites ( 325 to $310 \mathrm{Ma}$; Förster et al. 1999; Förster and Romer 2010; Tichomirowa et al. 2019). However, there are also some smaller magmatic stocks (e.g., Aue-Schwarzenberg granite suite) that are less fractionated and locally show ages $>330 \mathrm{Ma}$ (Tichomirowa and Leonhardt 2010). Post-collisional (sub-)volcanic rocks occur from 305 to $275 \mathrm{Ma}$ and are associated with crustal reorganization and the onset of Permian rifting (Hoffmann et al. 2013; Nasdala et al. 1998; Seckendorff et al. 2004).

The Erzgebirge is host to abundant greisen, skarn, and epithermal vein-type deposits genetically related to late- and post-collisional magmatic-hydrothermal activity in conjunction with the aftermath of the Variscan orogeny. Published geochronological data related to magmatic-hydrothermal mineralization spans ages from 326 to $276 \mathrm{Ma}$ (cf. Burisch et al. 2019b; Lefebvre et al. 2019; Ostendorf et al. 2019; Romer et al. 2007; Zhang et al. 2017). The time window in which $\mathrm{Sn}-\mathrm{W}( \pm \mathrm{Mo})$ greisen deposits formed has previously been constrained to 326 to $318 \mathrm{Ma}$ (Lefebvre et al. 2019; Romer et al. 2007; Zhang et al. 2017), which coincides with the emplacement of late-collisional highly fractionated peraluminous Li-mica granites (Förster et al. 1999; Tichomirowa et al. 2019).

A first generation of skarn is associated with the peak metamorphic event at $\sim 340$ Ma (Burisch et al. 2019b) and lacks significant metal endowment. Large and wellendowed Sn-Zn-In skarns have previously been associated with two distinct temporal stages. Skarns of the older stage formed at 325 to $313 \mathrm{Ma}$, overlapping closely with the age range reported for greisen deposits of the Erzgebirge; these are thought to be affiliated with the intrusion of latecollisional granitoids (Burisch et al. 2019b). In contrast, a younger stage of skarn formation in the Erzgebirge was dated to $308.1 \pm 3.6$ to $295.5 \pm 4.4 \mathrm{Ma}$, coinciding with post-collisional magmatism (Burisch et al. 2019b). These ages overlap within error with the $276 \pm 16 \mathrm{Ma}$ epithermal $\mathrm{Ag}-\mathrm{Pb}-\mathrm{Zn}$-veins of the Freiberg District that have tentatively been related to post-collisional magmatic activity (Bauer et al. 2019b; Burisch et al. 2019a; Ostendorf et al. 2019; Swinkels et al. 2021) and that represent the youngest record of magmatic-hydrothermal activity in the Erzgebirge.

The Schwarzenberg District in the western Erzgebirge (Fig. 1b) hosts prolific Sn-W-polymetallic skarn mineralization associated with laterally extensive meta-carbonate horizons (Lorenz and Hoth 1967) over an area of about $180 \mathrm{~km}^{2}$. The main skarn bodies in the Schwarzenberg District include the Globenstein W-Sn skarn as well as the Sn-Zn-In skarns of Breitenbrunn, Hämmerlein, and Antonstal (Fig. 1b). Total inferred resources reported for the district are $59.75 \mathrm{Mt}$ at $0.39 \mathrm{wt} \% \mathrm{Sn}, 15.85 \mathrm{Mt}$ at $0.42 \mathrm{wt} \% \mathrm{WO}_{3}, 60.62 \mathrm{Mt}$ at $1.01 \mathrm{wt} \% \mathrm{Zn}$, and $49 \mathrm{Mt}$ at
70.36 g/t In (cf. Anglo Saxony Mining Ltd. 2020; Hösel 2003; see Table ES1 for more details). The skarns vary significantly in size, metal endowment, and mineralogy, which has recently been attributed to differing spatial positions relative to their magmatic-hydrothermal fluid source(s) (Burisch et al. 2019b; Korges et al. 2019; Reinhardt et al. 2021). Skarns are mainly hosted by marble horizons within the meta-sedimentary sequences; however, metasomatism of gneisses and schists may also be observed (e.g., Hösel 2003; Hösel and Haake 1965; Lorenz and Hoth 1967; Meyer and Röthig 1967; Reinhardt et al. 2021). The skarns occur within distances of $<100$ to $>1000 \mathrm{~m}$ to the closest granite contact (cf. Hösel 2003; Schuppan and Hiller 2012). In the northern sector of the district, they tend to be smaller in volume and are characterized by a pyroxene-dominated mineralogy with disseminated base metal sulfides (Hösel and Haake 1965; Hoth et al. 2010), typical for skarns in a distal position relative to their causative intrusion (Meinert et al. 2005; Reinhardt et al. 2021). In contrast, skarns of the southern sector tend to be significantly larger in volume, are more proximal to a possibly causative intrusion, and are characterized by a higher abundance of garnet. Skarns of the southern sector comprise disseminated to massive lenses of magnetite that may reach up to several meters in thickness (e.g., Breitenbrunn, Globenstein, Hämmerlein skarns; cf. Hösel 2003; Hösel and Haake 1965; Hoth et al. 2010; Schuppan and Hiller 2012), disseminated to massive base metal sulfides (e.g., near monomineralic sphalerite bands up to several dm thick; Kern et al. 2019), and disseminated cassiterite and/or scheelite (e.g., Globenstein; Hösel 2003).

The paragenetic sequence of the skarns commonly starts with clinopyroxene (diopside-hedenbergite-johannsenite), grandite garnet, and magnetite followed by amphibole, epidote, quartz, chlorite, fluorite, and carbonate. Base metal sulfides (dominantly sphalerite and lesser galena, arsenopyrite, chalcopyrite, pyrite, löllingite etc.) as well as cassiterite and scheelite typically occur late in the paragenetic sequence and are thus mainly accompanied by quartz, fluorite, and chlorite (e.g., Hösel 2003; Hösel and Haake 1965; Kern et al. 2019; Reinhardt et al. 2021; Schuppan and Hiller 2012). One exception is the Globenstein skarn where scheelite also occurs intergrown with garnet without, e.g., chlorite and fluorite (see more details below). The skarns in the Schwarzenberg District may contain several generations of garnet. Garnet color, composition, and garnet/pyroxene ratio may vary spatially for a single magmatic-hydrothermal event as well as for consecutive skarn stages. This complexity, sometimes missing stages, and often intense retrograde alteration (Korges et al. 2019; Reinhardt et al. 2021) renders it challenging and sometimes even impossible to precisely correlate each garnet generation across hand specimens. 


\section{Methods}

In total, 28 skarn samples containing euhedral to subhedral garnet were cut to size and mounted in 1-inch epoxy rounds. Uranium- $\mathrm{Pb}$ garnet age data was subsequently collected on a ThermoFisher Element 2 sector field ICP-MS coupled with a Resonetics RESOLution S-155 $193 \mathrm{~nm}$ ArF Excimer laser equipped with a two-volume Laurin Technic ablation cell at the Frankfurt Isotope \& Element Research Center (FIERCE) of Goethe-Universität Frankfurt following the methodology described in Burisch et al. (2019b). Measurement points for each polished section derive from a small area $\left(<1 \mathrm{~cm}^{2}\right)$ and were set after careful screening to identify growth-zones with higher ${ }^{238} \mathrm{U} /{ }^{206} \mathrm{~Pb}$ ratios (Fig. 2) before each analytical session and to avoid superficial exposure of mineral inclusions by monitoring trace element ratios during screening. Samples were then analyzed in situ in fully automated mode overnight during two subsequent analytical sessions, sequence 1 and sequence 2. During the measurements, the signals of ${ }^{206} \mathrm{~Pb},{ }^{207} \mathrm{~Pb},{ }^{232} \mathrm{Th}$, and ${ }^{238} \mathrm{U}$ were acquired by peak jumping in pulse counting mode with a total integration time of c. $0.1 \mathrm{~s}$, resulting in 400 mass scans. The raw data was corrected offline deploying an in-house Microsoft Excel spreadsheet program (Gerdes and Zeh 2006, 2009). Mali grandite (dated by TIMS at $202.0 \pm 1.2 \mathrm{Ma}$; Seman et al. 2017) was used as a primary U-Pb age standard; garnet standards Lake Jaco (Seman et al. 2017) and MaliGUF (in-house reference material) were employed as secondary quality control standards. Common $\mathrm{Pb}$ correction has not been applied to the data due to its high variability although common $\mathrm{Pb}$ content was determined using the ${ }^{208} \mathrm{~Pb}$ signal after subtracting the radiogenic ${ }^{208} \mathrm{~Pb}$ (Millonig et al. 2012). Garnet $\mathrm{U}-\mathrm{Pb}$ ages are calculated using linear regression in Tera-Wasserburg Concordia diagrams (Tera and Wasserburg 1972) since the andradite-grossular solid solution incorporates a mixture of non-radiogenic and radiogenic $\mathrm{Pb}$ formed due to in situ decay of $\mathrm{U}$. Garnet $\mathrm{U}-\mathrm{Pb}$ dates are defined as the lower intercept with the Concordia curve as determined by linear regression of discordant arrays. Reported ages are based on multiple concordant analyses from one or more individual garnets and were calculated using Isoplot 3.71. All uncertainties are reported at the $2 \sigma$ level. After LA-ICP-MS analyses, all analyzed garnet samples were carbon-coated and the garnet composition of each sample was determined semiquantitatively by SEM-EDX using a FEI Quanta 600F scanning electron microscope (SEM) equipped with two Bruker X-Flash EDX detectors located at the Institute of
Fig. 2 Back-scattered electron (BSE) images of laser ablation spots in representative garnet samples of the Schwarzenberg District. Laser ablation pits related to sample pre-screening are highlighted in red color and laser ablation pits of actual measurements (including spot analysis number) are indicated in green color. A Laser ablation pits in andraditic (Fe-rich) zones of garnet aggregates from the Hämmerlein skarn (Pöh33A). B Laser ablation spots in the relatively andradite-rich rim of a garnet crystal from the Globenstein skarn (LfULG13B). Note that measurement attempts in the more grossularrich core have not been successful for this particular sample. C Zoned euhedral grandite garnet from the Breitenbrunn skarn (9890B). D Laser ablation spots in andradite-rich rims of grandite from the Hämmerlein skarn (Pöh-3C)

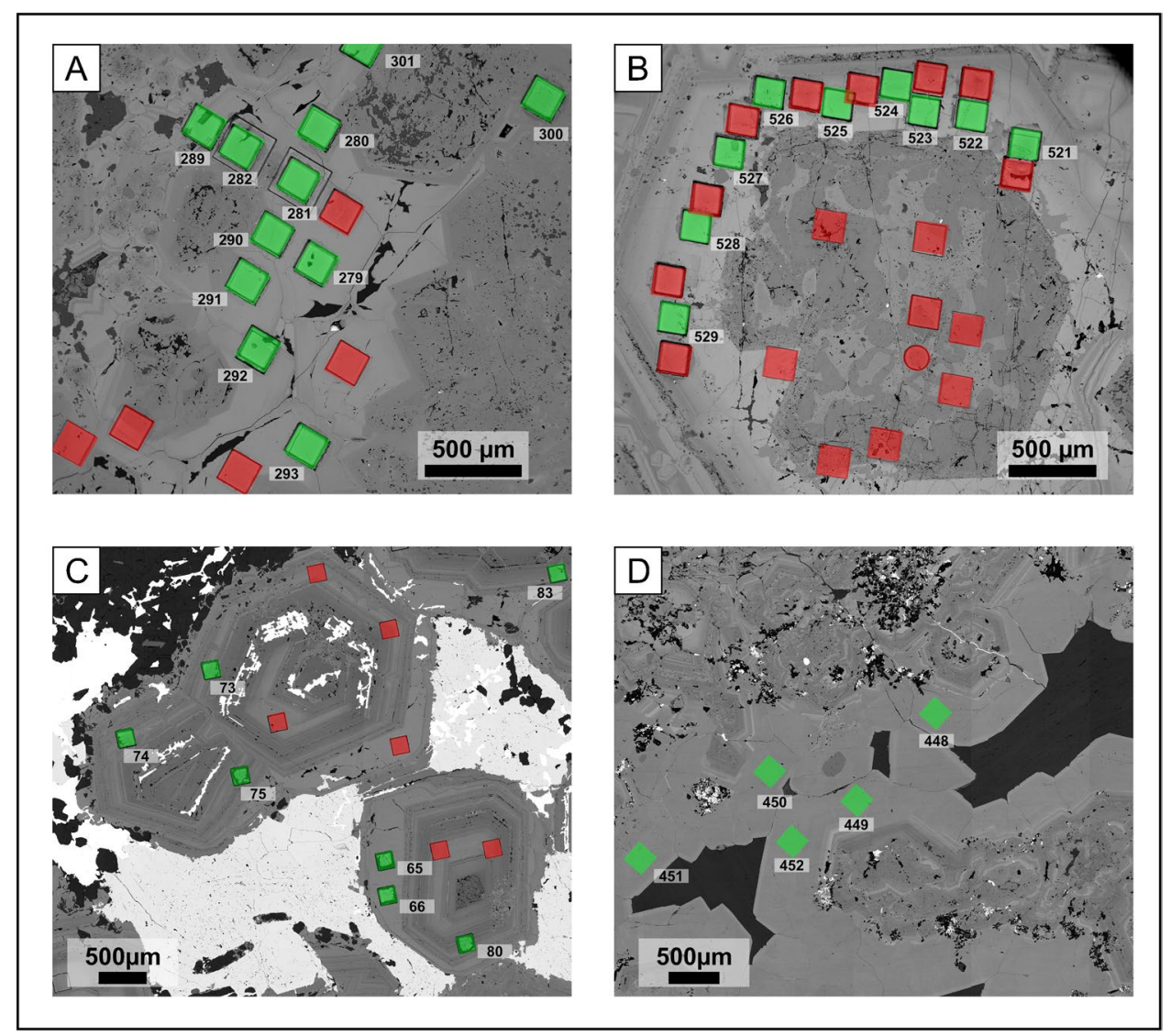


Mineralogy of the TU Bergakademie Freiberg to confirm petrographic observations. An acceleration voltage of $25 \mathrm{kV}$, a beam current of $10 \mathrm{nA}$, and a beam diameter of $5.8 \mu \mathrm{m}$ were used during semi-quantitative EDX measurements.

\section{Results}

Eighteen garnet samples (609 individual spot analyses) were successfully dated by U-Pb LA-ICP-MS. Although sample pre-screening identified andradite-rich growth zones as most suitable for analysis, there seems to be no clear trend between andradite component and U content of garnet (Fig. 2). Semiquantitative garnet composition, $\mathrm{U}$ and $\mathrm{Pb}$ concentrations, and calculated $\mathrm{U}-\mathrm{Pb}$ ages are provided in Table 1. Detailed descriptions of the samples, sample localities, and associated GPS coordinates are summarized in electronic supplement Table ES2. Uncorrected isotopic data may be found in Table ES3 of the electronic supplement. A histogram of the garnet age distribution in the Schwarzenberg District, analytical errors of individual samples, and Tera-Wasserburg Concordia diagrams of selected samples are shown in Fig. 5. An overview of measurement points on all samples, histograms of the garnet age distribution of individual deposits, and an overview of all Tera-Wasserburg Concordia diagrams are provided in Figures ES4, ES5, and ES6 of the electronic supplement, respectively. The available garnet ages of the entire Erzgebirge are summarized in Fig. 6. Although several generations of garnet may occur on the deposit scale, each of the 1-inch round mounts, that were used for geochronology, does only contain one garnet generation.

\section{Antonsthal}

The Antonsthal skarn is dominated by fine-grained diopsiderich clinopyroxene accompanied by pale red to brown subhedral to euhedral grossular-rich grandite garnet (Fig. 3a). Sphalerite, galena, cassiterite, and lesser chalcopyrite, pyrite, and arsenopyrite occur paragenetically late and are associated with chlorite, quartz, fluorite, and calcite (Fig. 4a). Uranium and $\mathrm{Pb}$ contents in grandite vary from 0.09 to $118.09 \mu \mathrm{g} / \mathrm{g}$ and 0.07 to $15.39 \mu \mathrm{g} / \mathrm{g}$, respectively. Three garnet samples yield overlapping lower intercept ages of $312.6 \pm 3.9 \mathrm{Ma}, 319.6 \pm 5.2 \mathrm{Ma}$, and $320.3 \pm 3.2 \mathrm{Ma}$ (Fig. 5b, c).

Table 1 Laser-ablation U-Pb ages of garnet from the Schwarzenberg District

\begin{tabular}{|c|c|c|c|c|c|c|c|}
\hline Sample number & $\begin{array}{l}\text { Garnet } \\
\text { composition }^{1}\end{array}$ & $\mathrm{U}-\mathrm{Pb}$ age $(\mathrm{Ma})$ & MSWD & Initial ${ }^{207} \mathrm{~Pb} /{ }^{206} \mathrm{~Pb}$ & Garnet $[\mathrm{U}](\mu \mathrm{g} / \mathrm{g})$ & Garnet total $[\mathrm{Pb}](\mu \mathrm{g} / \mathrm{g})$ & $N$ \\
\hline \multicolumn{8}{|l|}{ Antonsthal skarn } \\
\hline $10622 C$ & Grs-Adr & $312.6 \pm 3.9$ & 1.45 & 0.8648 & 0.15 to 3.21 & 0.12 to 0.85 & 32 \\
\hline LfULG-22_1 & Grs-Adr & $320.3 \pm 3.2$ & 1.01 & 0.8587 & 2.53 to 118.09 & 0.56 to 6.54 & 32 \\
\hline$L f U L G-22 \_2$ & Grs-Adr & $319.6 \pm 5.2$ & 2.07 & 0.8475 & 0.09 to 32.27 & 0.07 to 15.39 & 26 \\
\hline \multicolumn{8}{|l|}{ Breitenbrunn skarn } \\
\hline $9890 B$ & Adr-Grs & $337.5 \pm 3.3$ & 1.46 & 0.8545 & 0.15 to 7.57 & 0.05 to 4.56 & 25 \\
\hline 65562 & Grs-Adr & $315.1 \pm 5.9$ & 0.89 & 0.8613 & 1.15 to 62.94 & 0.82 to 34.70 & 38 \\
\hline 65682 & Grs-Adr & $317.3 \pm 6.3$ & 0.76 & 0.8597 & 0.20 to 40.92 & 0.74 to 119.94 & 36 \\
\hline$S C-3-1$ & Grs-Adr & $313.5 \pm 4.7$ & 1.39 & 0.8591 & 0.13 to 102.57 & 0.09 to 33.68 & 29 \\
\hline$S C-3-2 B$ & Grs-Adr & $314.9 \pm 2.5$ & 1.24 & 0.8640 & 0.10 to 22.25 & 0.10 to 2.20 & 52 \\
\hline$S C-3-2 C$ & Grs-Adr & $316.5 \pm 2.7$ & 1.19 & 0.8717 & 0.06 to 158.47 & 0.21 to 17.12 & 46 \\
\hline \multicolumn{8}{|l|}{ Hämmerlein skarn } \\
\hline Pöh-3C & Adr-Grs & $304 \pm 5.7$ & 1.52 & 0.8676 & 0.17 to 0.62 & 0.03 to 0.37 & 36 \\
\hline P̈̈h-16A & Grs-Adr & $294 \pm 8.3$ & 2.13 & 0.8609 & 0.13 to 5.27 & 0.03 to 1.84 & 33 \\
\hline Pöh-33A & Adr-Grs & $324.3 \pm 7.4$ & 3.33 & 0.8637 & 0.10 to 2.51 & 0.09 to 2.33 & 29 \\
\hline$+590-554 B$ & Grs-Adr & $327.3 \pm 8.4$ & 1.52 & 0.8643 & 0.05 to 6.93 & 0.18 to 2.79 & 25 \\
\hline \multicolumn{8}{|l|}{ Globenstein skarn } \\
\hline$L f U L G-13 A$ & Adr-Grs & $338.2 \pm 2.5$ & 1.13 & 0.8546 & 0.07 to 2.99 & 0.03 to 0.45 & 26 \\
\hline$L f U L G-13 B$ & Adr-Grs & $331.2 \pm 3.0$ & 1.03 & 0.8641 & 0.45 to 5.98 & 0.20 to 18.06 & 58 \\
\hline$+350-1197 B$ & Grs-Adr & $336.4 \pm 3.7$ & 1.60 & 0.8571 & 0.05 to 1.16 & 0.03 to 2.02 & 27 \\
\hline$+350-1152 B$ & Adr-Grs & $337.8 \pm 3.2$ & 1.14 & 0.8514 & 0.41 to 2.95 & 0.09 to 0.77 & 30 \\
\hline 9755 & Adr-Grs & $337.1 \pm 3.6$ & 1.35 & 0.8565 & 0.63 to 6.15 & 0.14 to 3.24 & 29 \\
\hline
\end{tabular}

${ }^{1}$ Garnet composition was determined semi-quantitatively by means of SEM-EDX; MSWD: mean square of weighted deviates; N: number of spot analyses; Adr-Grs: andradite-grossular solid solution, andradite-rich; Grs-Adr: andradite-grossular solid solution, grossular-rich 
Fig. 3 Representative hand specimens and related epoxy mounts ( $2.5 \mathrm{~cm}$ diameter $)$ of samples from the four analyzed skarn prospects of the Schwarzenberg District. A Fine-grained pyroxene skarn (sample 10622), drift 9 1/2-1, level $91 \frac{1}{2}$, shaft 235, Antonsthal. B Coarse-grained garnet-pyroxene skarn (sample SC-3-2), "westlicher Überhaun," west field, St.-Christoph mine, Breitenbrunn. C Coarse-grained garnet skarn (sample Pöh-3), cross-drift 2, $590 \mathrm{~m}$ level, adit Pöhla, Hämmerlein. D Coarsegrained garnet-pyroxene skarn (sample +350-1197), drift 103A, $350 \mathrm{~m}$ level, shaft 24, Globenstein. Px: pyroxene; Grt: garnet; Amp: amphibole; Sp:, sphalerite; Sch: scheelite

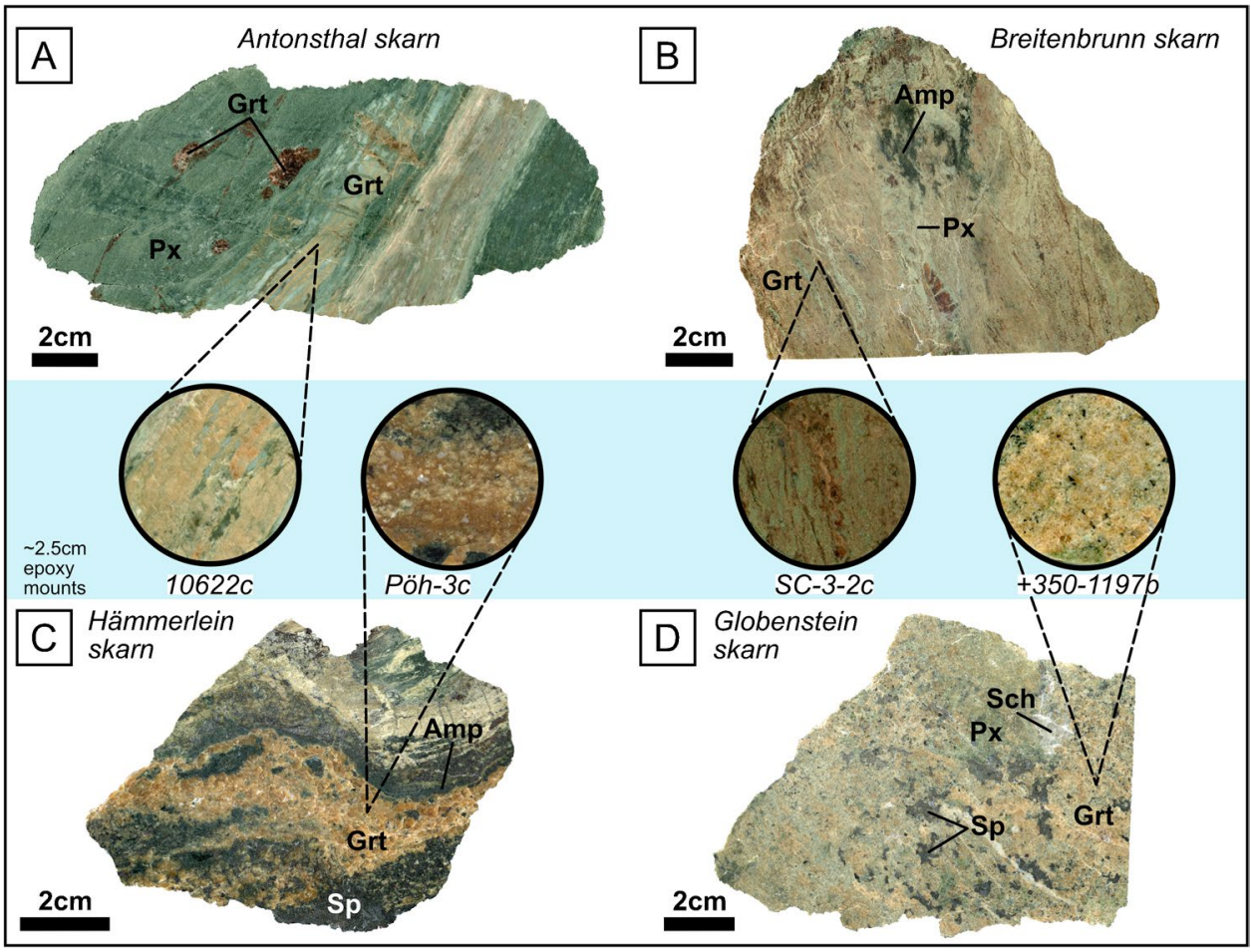

\begin{tabular}{|c|c|c|c|c|}
\hline Antonsthal & & A & $\begin{array}{c}\text { Breiten- } \\
\text { brunn }\end{array}$ & B \\
\hline$P x+G r t$ & $=1$ & & $P x+G r t$ & I + II $+\underbrace{I I I}=-$ \\
\hline $\begin{array}{l}\text { Mag+Ep+Ves+ } \\
\text { Amp+Hem }\end{array}$ & - & & $\begin{array}{l}\text { Mag+Ep+Ves+ }+ \text { + } \\
\text { Amp+Qtz+Fl+ } \\
\text { Cal+Hem }\end{array}$ & $\stackrel{?}{a}--$ \\
\hline $\begin{array}{l}\mathrm{Chl}+\mathrm{Qtz}+\mathrm{Fl}+ \\
\mathrm{Cal}+\mathrm{Cst}+\text { Sulf }\end{array}$ & & & $\begin{array}{c}\text { Chl+Prh+Cst } \\
\text { Sulf }\end{array}$ & \\
\hline Hämmerlein & & $\mathrm{C}$ & Globenstein & D \\
\hline $\mathrm{Px}+\mathrm{Grt}+\mathrm{Fsp}$ & $=-\left\|^{\|}-\right\|^{\| I I}$ & & $P x+G r t$ & 1 \\
\hline$E p+A m p+M a g$ &.---- & & $\begin{array}{c}\text { Mag+Ep+Ves+ } \\
\text { Amp+Lu }\end{array}$ & ---- \\
\hline $\begin{array}{l}\text { Chl+Ser+Qtz+ } \\
\text { Fl+Cal+Hem+ } \\
\text { St+Cst+Sulf }\end{array}$ & & & $\begin{array}{c}\text { Chl+Ser+Qtz+ }+ \\
\mathrm{Fl}+\text { Cst+Ssch } \\
\text { Sulf }\end{array}$ & \\
\hline
\end{tabular}

Fig. 4 Simplified paragenetic sequences for the A Antonsthal, B Breitenbrunn, C Hämmerlein, and D Globenstein skarns. The paragenetic positions of grandite garnet and ore minerals (cassiterite, scheelite, and sulfides) have been highlighted in green (garnet) and orange (cassiterite, scheelite, sulfides). The paragenetic sequences have been compiled from Gärtner (2019), Hösel (2003), Hösel and Haake (1965), Hoth et al. (2010), Schuppan and Hiller (2012) and have been complemented by petrographic observations conducted

\section{Breitenbrunn}

The Breitenbrunn skarn comprises two major skarn bodies that can be traced for more than $4 \mathrm{~km}$ along strike (Hösel and Haake 1965). The early-stage mineralogy is dominated by during this study. Note that the paragenetic sequences are strongly simplified and that the skarns may exhibit distinct local mineralogical variations. Px:, pyroxene; Grt:, garnet; Fsp: feldspar; Amp: amphibole; Ep: epidote; Ves:, vesuvianite; Mag:, magnetite; Hem: hematite; Chl: chlorite; Qtz: quartz; Fl: fluorite; Cal:, calcite; Prh: prehnite; Ser: sericite; St: stokesite; Lu: ludwigite; Cst: cassiterite; Ssch:, scheelite; Sulf: sulfides

pale green clinopyroxene (diopside-hedenbergite), reddishbrown fine- to medium-grained grandite garnet (Fig. 3b, 4b), and magnetite, which may form massive lenses up to $5 \mathrm{~m}$ in thickness (Hösel and Haake 1965; Hoth et al. 2010). The intensity of retrograde alteration is relatively weak and may 
Fig. 5 A Histogram of the garnet age distribution of skarns in the Schwarzenberg District. Garnet ages cluster around three maxima at 340-335 Ma, 325-315 Ma, and 305-300 Ma (this study; Burisch et al. 2019b). B Distribution of individual sample ages and associated uncertainties for the Schwarzenberg District ( $n=25$ samples). The range of geochronological data related to granite stocks of the Aue-Schwarzenberg suite ( 334 to $322 \mathrm{Ma}$ ) and the Eibenstock Li-mica granite (326 to $311 \mathrm{Ma}$ ) are indicated as boxes above the garnet ages (Tichomirowa et al. 2019; Tichomirowa and Leonhardt 2010). C-F Selected Tera-Wasserburg Concordia diagrams of skarn-related garnet LA-ICP-MS analyses from the C Antonsthal, D Breitenbrunn, E Hämmerlein, and F Hämmerlein Globenstein skarn prospects. All data-point error ellipses represent $2 \sigma$ uncertainties. Calculated garnet ages are reported as lower intercept ages. MSWD: mean square of weighted deviates; $n$ : number of analyses. PG:, Pöhla-Globenstein; AT:, Antonsthal; BB: Breitenbrunn; PH: Pöhla-Hämmerlein; GB: Gelbe Birke

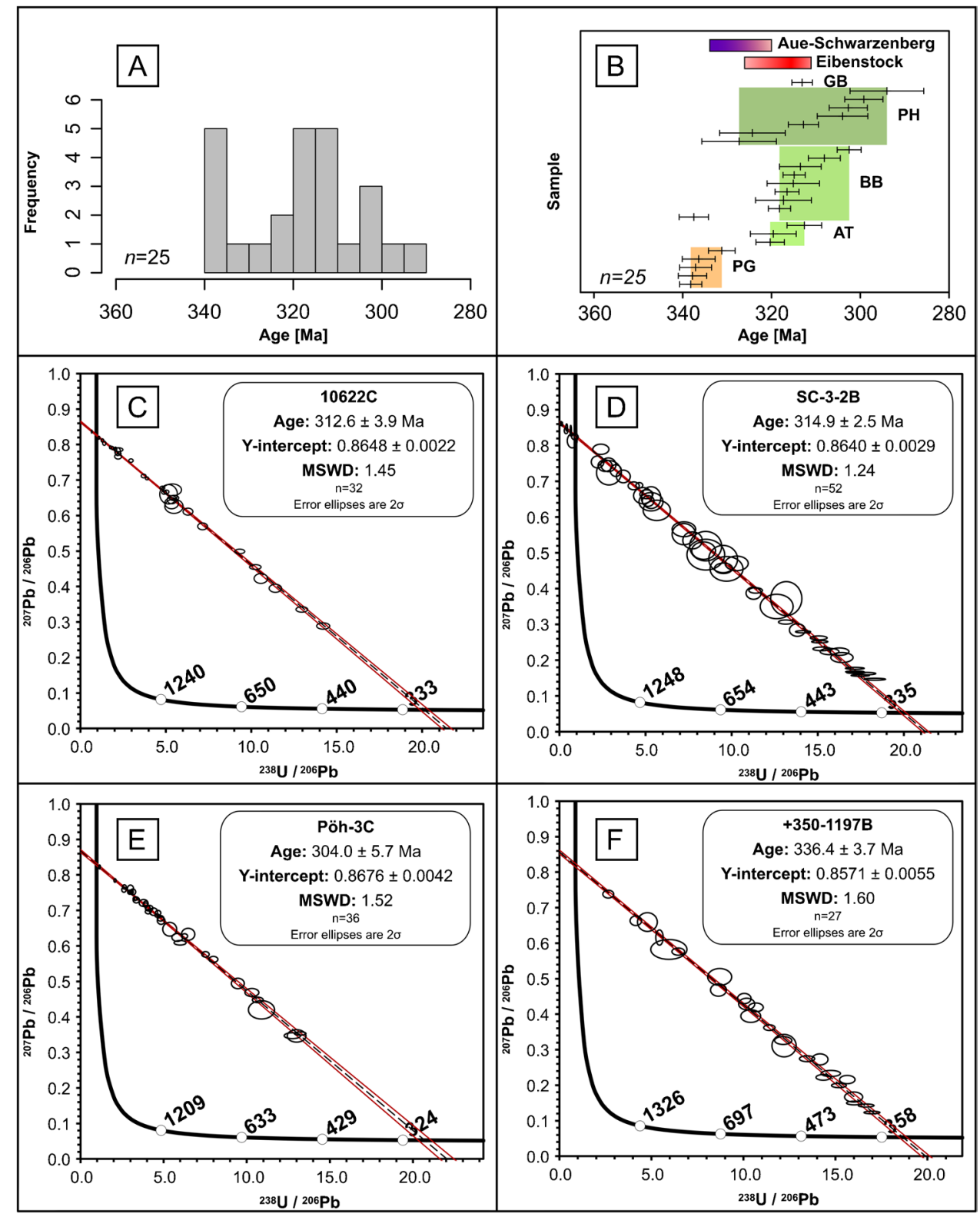

include variable proportions of amphibole, epidote, vesuvianite, quartz, chlorite, prehnite, and carbonate (Fig. 4b). Disseminated cassiterite and sulfides are invariably associated with the retrograde stage (Fig. 4b), with sulfides being dominated by sphalerite and galena. Dump sample 9890B (Table 1) from the southern sector of the Breitenbrunn skarn (Fortuna mine) consists of pale green euhedral coarse-grained garnet pre-dating magnetite and sphalerite. However, due to the lack of field evidence, the paragenetic position of this garnet relative to other garnet generations at the Breitenbrunn skarn remains unconstrained. The chemical composition of garnet varies from low to high andradite proportions within the grandite solid solution. Uranium and $\mathrm{Pb}$ contents range from 0.06 to $158.47 \mu \mathrm{g} / \mathrm{g}$ and 0.05 to $119.94 \mu \mathrm{g} / \mathrm{g}$, respectively. Reddish-brown fine-to medium-grained garnet from pyroxene-garnet skarn shows overlapping lower intercept ages between $317.3 \pm 6.3 \mathrm{Ma}$ and 313.5 $\pm 4.7 \mathrm{Ma}$ (Fig. 5b, d). The pale green garnet sample does not fall into this range and yields a considerably older lower intercept age of $337.5 \pm 3.3 \mathrm{Ma}$.

\section{Hämmerlein}

The Hämmerlein-Tellerhäuser skarn complex comprises three skarn units (Hämmerlein, Dreiberg, and Zweibach, cf. Bauer et al. 2019a) that extend laterally for more than $5 \mathrm{~km}$ (see Fig. 1b). Samples studied here are invariably related to the Hämmerlein unit (cf. Schuppan and Hiller 2012). Skarn is mainly composed of clinopyroxene (diopside-hedenbergite), pale red to green euhedral grandite garnet and epidote, 
Fig. 6 Skarn formation in the context of the geotectonic and magmatic evolution of the Erzgebirge. Relative frequency of A late-collisional granite intrusions, $\mathbf{B}$ post-collisional igneous rocks, and $\mathbf{C}$ skarns in the Erzgebirge. D Summary of skarn-related garnet ages within the geotectonic framework of the Erzgebirge. The age ranges of skarn stages I to III are indicated. n:, number of analyzed samples. Sources: Burisch et al. 2019b; Förster 1999; Förster and Romer 2010; Gehmlich et al. 2001; Hoffmann et al. 2013; Hofmann et al. 2009; Hübner et al. 2020; Kováříková et al. 2007; Kröner and Willner 1998; Lefebvre et al. 2019; Luthardt et al. 2018; Nasdala et al. 1998; Ostendorf et al. 2019; Quadt 1993; Romer et al. 2007; Romer et al. 2010; Seckendorff et al. 2004; Tichomirowa et al. 2019; Tichomirowa and Leonhardt 2010; Zhang et al. 2017
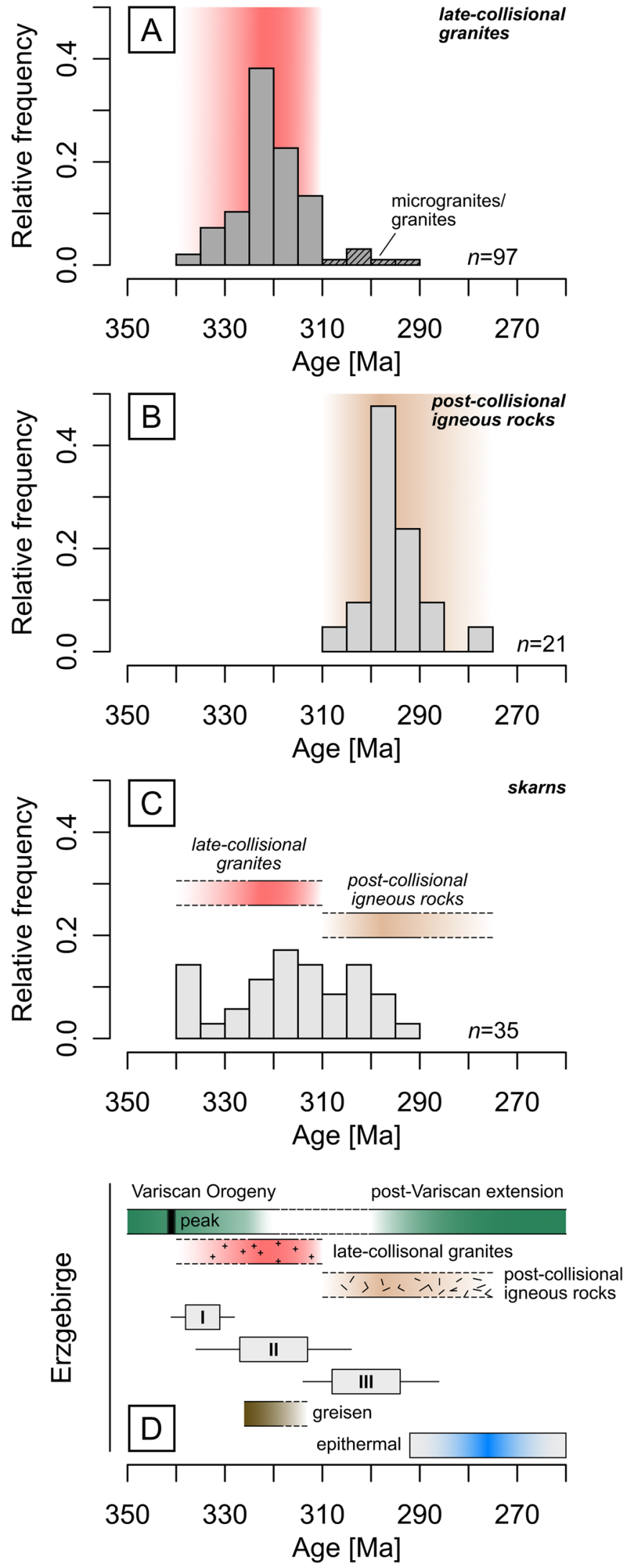
and fine-grained skarnoid domains that are composed of feldspar, clinopyroxene, and epidote (Fig. 4c). Intense retrograde alteration is recognized, which is characterized by early amphibole and magnetite, followed by late-stage chlorite, quartz, fluorite, and carbonate (Fig. 4c). Disseminated cassiterite and sphalerite as well as minor chalcopyrite, arsenopyrite, and galena accompany late-stage chlorite and quartz (Kern et al. 2019; Schuppan and Hiller 2012). The late-paragenetic position of ore minerals is furthermore supported by relatively low homogenization temperatures (185 to $220^{\circ} \mathrm{C}$ ) in sphalerite (Korges et al. 2019; Schuppan and Hiller 2012). Locally, sphalerite may form almost monomineralic bands that comprise late-stage coarse-grained euhedral pale brownish-orange to greenish grandite garnet (cf. Kern et al. 2019; Schuppan and Hiller 2012; Fig. 3c). Garnet varies strongly from andradite- to grossular-dominated compositions and has $\mathrm{U}$ and $\mathrm{Pb}$ contents that vary from 0.05 to $6.93 \mu \mathrm{g} / \mathrm{g}$ and 0.03 to $2.79 \mu \mathrm{g} / \mathrm{g}$, respectively. Lower intercept ages of pale red to green garnet from pyroxene-garnet skarn with metasomatic or skarnoid textures are in the range of $327.3 \pm 8.4 \mathrm{Ma}$ to $324 \pm 7.4 \mathrm{Ma}$, whereas pale brownish to greenish garnet intergrown with sphalerite yields younger ages of $304 \pm 5.7$ to $294 \pm 8.3 \mathrm{Ma}$ (Fig. 5b, e).

\section{Globenstein}

The Globenstein prospect consists of two marble horizons with variable degrees of metasomatism. The deeper marble horizon hosts two intensely metasomatized skarn layers (Lager 3 and Lager 4), whereas less intense metasomatism affects the hanging-wall marble horizon (Lager 5; Hösel 2003).

The prograde skarn assemblage at the Globenstein skarn is mainly composed of clinopyroxene (diopside-hedenbergite) and medium- to coarse-grained euhedral pale green to brown grandite garnet (Figs. 3d, 4d). Prograde skarn is often replaced by amphibole, epidote, vesuvianite, quartz, fluorite, and chlorite (Fig. 4d). Magnetite occupies a paragenetic position between prograde and retrograde skarn mineral assemblages and forms semi-massive to massive lenses of up to several meters in thickness ( $9 \mathrm{~m}$ maximum; Hösel 2003). Cassiterite, scheelite, and sulfide minerals are mainly associated to chlorite, fluorite, and quartz of the retrograde stage (Fig. 4d). However, scheelite may also occur as coarsegrained aggregates which are intergrown with garnet. Although scheelite seems to be paragenetically younger than garnet, the conspicuous absence of associated retrograde minerals such as chlorite and fluorite with this scheelite type suggests that it may pre-date the retrograde assemblage (cf. Hösel 2003). In the samples dated in this study, scheelite is associated with quartz and forms aggregates interstitial to garnet and pyroxene. Garnet compositions at Globenstein span a wide range of andradite-grossular proportions.
Uranium and $\mathrm{Pb}$ contents vary from 0.05 to $6.15 \mu \mathrm{g} / \mathrm{g}$ and 0.03 to $18.06 \mu \mathrm{g} / \mathrm{g}$, respectively. Lower intercept ages of all analyzed samples overlap within error and vary from $338.2 \pm 2.5$ Ma to $331.2 \pm 3.0$ Ma (Fig. 5b, f).

\section{Discussion}

\section{Timing of skarn formation in the Schwarzenberg District}

The broad range of garnet ages in the Schwarzenberg District indicates that skarn formation during the Variscan orogenic cycle is not constrained to a narrow window, but occurs episodically over a broad interval from $\sim 338$ to $294 \mathrm{Ma}$ (Fig. 5, Table 1). This result is in excellent agreement with the regional study of Burisch et al. (2019b). The four major skarn bodies of this district - Globenstein, Breitenbrunn, Anthonsthal, and Hämmerlein — show distinctively different ages and age ranges, suggesting that they do not originate from the same fluid-source/intrusion.

Five garnet samples from the Globenstein skarn have, within their errors, very similar ages $(338.2 \pm 2.5 \mathrm{Ma}$ to $331.2 \pm 3.0 \mathrm{Ma}$ ) suggesting that at least the prograde evolution of this $\mathrm{W}$-dominated skarn is related to a single magmatichydrothermal event occurring soon after the regional peak metamorphic event (341 $\pm 1 \mathrm{Ma}$; Kröner and Willner 1998). Textural, geochemical, and mineralogical arguments, including the coarse-grained isometric habit of the garnet and the observation that garnet overprints metamorphic features of the host rock (e.g., Hösel 2003; Lorenz and Hoth 1967), strongly support a magmatic-hydrothermal origin of the Globenstein skarn. Although scheelite and cassiterite post-date the prograde skarn stage, it is likely that they are related to the retrograde stage of the same magmatic-hydrothermal event, since available geochronological data and petrographic observations do not suggest a polyphase evolution of the Globenstein skarn. Nevertheless, the presented garnet ages constrain the prograde evolution at Globenstein and, hence, have to be regarded as a maximum age for the retrograde stage and associated W-Sn mineralization (see Fig. 4d).

The age obtained for the Globenstein W-Sn skarn can tentatively be linked to granitic stocks of the Aue-Schwarzenberg suite nearby, with ages of $334 \pm 12$ to $329 \pm 3 \mathrm{Ma}(\mathrm{U}-\mathrm{Pb}$ zircon ages; Tichomirowa and Leonhardt 2010). The garnet ages of the Globenstein skarn presented here thus reflect the oldest record of magmatic-hydrothermal fluid flow in conjunction with the Variscan orogeny in the Erzgebirge (cf. Burisch et al. 2019b; Förster et al. 1999; Zhang et al. 2017), yet the significance of these ages for the timing of Sn-W mineralization in the area is not yet fully explored.

Although located in the immediate vicinity of the Globenstein skarn, the Breitenbrunn, Antonsthal, and Hämmerlein 
skarn have a distinctly different metal tenor ( $\mathrm{Zn}, \mathrm{Sn}, \mathrm{In})$ and show a more complex distribution of garnet ages. This observation is used here as evidence that these three skarns may record a series of successive and temporally distinct (prograde) magmatic-hydrothermal events.

Available garnet ages suggest the presence of at least three distinct hydrothermal events at the Breitenbrunn skarn. Most of the garnet ages related to this skarn fall into the range of 317 to $313 \mathrm{Ma}$, which correlates well with $\mathrm{U}-\mathrm{Pb}$ zircon ages of the proximal Eibenstock granite $(\sim 315$ to $314 \mathrm{Ma}$; Tichomirowa et al. 2019; Tichomirowa and Leonhardt 2010) and also agrees well with garnet ages recorded for the Antonsthal skarn. Nevertheless, one garnet age of $337.5 \pm 3.3 \mathrm{Ma}$ records an older magmatic-hydrothermal event that coincides with the age of the Globenstein skarn. Two previously published garnet ages of $308.1 \pm 3.6$ and $302 \pm 2.7 \mathrm{Ma}$ for the Breitenbrunn skarn (cf. Burisch et al. $2019 b$ ) provide evidence for a third, younger magmatichydrothermal event, which post-dates the emplacement of all known granitic intrusions in the area.

Garnet ages obtained for the Hämmerlein skarn prospect are again distinctly different. The paragenetically oldest garnet, which pre-dates the ore stage (Kern et al. 2019), has ages ranging from $327.3 \pm 8.4$ to $324.3 \pm 7.4 \mathrm{Ma}$, overlapping both with the youngest $\mathrm{U}-\mathrm{Pb}$ zircon ages of the AueSchwarzenberg granite suite (334 to $322 \mathrm{Ma}$; Tichomirowa et al. 2019; Tichomirowa and Leonhardt 2010) and the oldest magmatic records of the emplacement of the Eibenstock granite ( $315 \mathrm{Ma})$. One single garnet age of $312.8 \pm 3.4 \mathrm{Ma}$ (Burisch et al. 2019b) at Hämmerlein may record magmatichydrothermal activity related to the main emplacement stage of the Eibenstock granite (Tichomirowa et al. 2019). The majority of garnet ages from this deposit $(304 \pm 5.7$ to $294 \pm 8.3 \mathrm{Ma}$ ), however, are related to paragenetically late garnet associated with massive sphalerite bands. These garnet ages are significantly younger than all known granite intrusions in the Schwarzenberg District. Yet, they coincide with post-collisional volcanic lithologies in the larger region that lack exposed plutonic equivalents (c.f. Burisch et al. 2019b; Hoffmann et al. 2013; Kroner and Romer 2013; Seckendorff et al. 2004). Therefore, the main episode of fertile skarn formation at Hämmerlein is tentatively related to this late, post-collisional magmatic event.

The broad range of skarn-related garnet ages in the Schwarzenberg District indicates that skarn formation in the district has been polyphase and not restricted to a narrow time window. The formation of metal-endowed skarns is by no means related exclusively to the emplacement of late-collisional Li-mica granites as often assumed in previous studies (cf. Förster et al. 1999; Lefebvre et al. 2019; Romer et al. 2007; Zhang et al. 2017). Instead, skarn formation in the Schwarzenberg District occurred episodically within a broad time interval of up to $\sim 40 \mathrm{Ma}$.

\section{Timing of skarn formation in the Erzgebirge}

In their regional study across the Erzgebirge, Burisch et al. (2019b) identified skarns of regional metamorphic origin associated with peak regional metamorphism at $\sim 340 \mathrm{Ma}$. However, these skarns are typically barren and are, hence, not discussed further here. Burisch et al. (2019b) also delineated two main windows of fertile skarn formation across the Erzgebirge, at 325 to $313 \mathrm{Ma}$ and $\sim 308$ to $295 \mathrm{Ma}$. These were related to late- and post-collisional magmatic activity (Burisch et al. 2019b). Most of the geochronological data presented in this study for fertile skarn bodies of the Schwarzenberg District are in excellent agreement with these results. However, 338 to $331 \mathrm{Ma}$ garnet dates related to the Globenstein W-Sn skarn provide evidence for a previously unrecognized magmatichydrothermal episode. In the following, we use available garnet age data and compare it to published geochronological data of igneous rocks and hydrothermal mineralization from the Erzgebirge to define temporal windows and geological environments in which fertile skarn formation occurred during the Variscan orogenic cycle.

\section{Stage I}

Garnet ages of $>335 \mathrm{Ma}$ in the Schwarzenberg District are restricted to the Globenstein and Breitenbrunn skarns (Fig. 5b, Table 1) and reflect the oldest record of magmatic-hydrothermal fluid flow associated with the Variscan orogeny in the Erzgebirge (cf. Burisch et al. 2019b; Lefebvre et al. 2019; Romer et al. 2007; Zhang et al. 2017). Oldest garnet ages from the Globenstein and Breitenbrunn skarns overlap within error with the peak of regional metamorphism in the Erzgebirge at $341 \pm 1$ Ma (Fig. 6d; Kröner and Willner 1998), but textural evidence as well as the close proximity to granites of similar age support that magmatic-hydrothermal skarns locally already formed in the immediate aftermath of peak metamorphism. Despite the remaining uncertainty regarding the age of scheelite in these skarns, the narrow range of garnet ages and the anomalous $\mathrm{W}$-endowment of the Globenstein prospect compared to all other skarns known in the Erzgebirge may reflect an early fertile skarn stage with particular exploration significance for $\mathrm{W}$.

\section{Stage II}

Most ages of garnets in skarns of the Schwarzenberg District and across the Erzgebirge fall into the interval from 327 to $310 \mathrm{Ma}$ (Table 1, Fig. 6c; this study; Burisch et al. 2019b); this age range coincides with the emplacement of abundant Li-mica granites (Fig. 6a; Förster et al. 1999; Förster 
and Romer 2010; Hofmann et al. 2009; Kováŕíková et al. 2007; Tichomirowa et al. 2019; Tichomirowa and Leonhardt 2010) as well as the age of greisen-hosted Sn mineralization (Fig. 6d). Notably, the oldest garnet ages at Hämmerlein $(327.3 \pm 8.4$ and $324.3 \pm 7.4 \mathrm{Ma})$ overlap, due to their large errors, with stages I and II. However, based on petrographic evidence these ages have been related to stage II. The skarns in this age range have a $\mathrm{Sn}-\mathrm{Zn}$-(In) tenor (e.g., Bauer et al. 2019a; Hösel 1994; Kern et al. 2019; Schuppan and Hiller 2012). Due to their size and regional abundance, these skarns represent the most important targets of mineral exploration in the Erzgebirge (e.g., Anglo Saxony Mining Ltd. 2020; Burisch et al. 2019b; Hösel 1994; Schuppan and Hiller 2012).

\section{Stage III}

A significant number of garnet ages across the Erzgebirge are in the range of $\sim 310$ to $295 \mathrm{Ma}$ (Table 1, Fig. 6c; this study; Burisch et al. 2019b) and reflect the youngest record of skarnforming hydrothermal activity in the Erzgebirge (Burisch et al. 2019b). This skarn-forming event significantly post-dates the emplacement of voluminous granitic intrusions (cf. Förster et al. 1999; Förster and Romer 2010; Tichomirowa et al. 2019; Tichomirowa and Leonhardt 2010), but coincides with widespread post-collisional (sub)-volcanic units (Fig. 6b; this study; Burisch et al. 2019b). It is tentatively suggested that these garnet ages point to yet undiscovered (small) intrusions and related mineralization. Common trait of skarns that yield garnets of this age range, such as the Hämmerlein skarn, is their polyphase origin. They can be of considerable size and grade (e.g., Hämmerlein skarn; Anglo Saxony Mining Ltd. 2020; Hösel 1994; Schuppan and Hiller 2012), but it remains uncertain to which stage(s) of skarn formation they owe their metal endowment.

\section{Timing of magmatic-hydrothermal mineral systems in the Variscan Belt}

To gain an overview of the timing of magmatic-hydrothermal ore formation on the scale of the entire European Variscan Belt, we incorporated published geochronological data (e.g., this study; Burisch et al. 2019b; Harlaux et al. 2018; Moscati and Neymark 2020; Zhang et al. 2019) into the existing geochronological framework of the main Variscan Sn-W provinces (Fig. 7). In all internal zones of the Variscan Orogenic Belt (e.g., the French Massif Central/France, the Iberian Massif/Spain, and the Erzgebirge/Germany), the onset of magmatic-hydrothermal activity occurred simultaneously at approximately $\sim 335 \mathrm{Ma}$ (Fig. 7; this study; Harlaux et al. 2018; Zhang et al. 2019). This onset of magmatic-hydrothermal activity occurred less than $5 \mathrm{Ma}$ after the peak metamorphic event. The youngest magmatichydrothermal record in the internal zones also occurred at

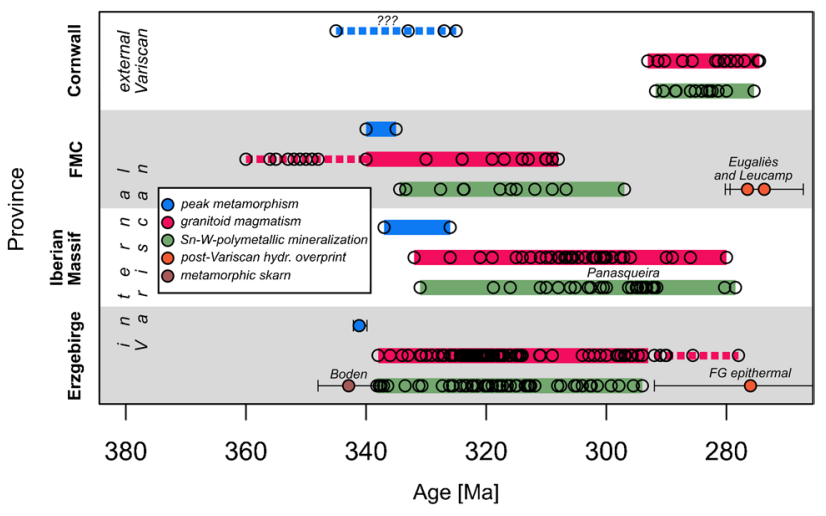

Fig. 7 Comparison of peak metamorphism, ages of igneous units and $\mathrm{Sn}-\mathrm{W}$-polymetallic mineralization related to the Variscan orogenic cycle in internal and external zones of the European Variscan Belt. FMC: French Massif Central; blue:, peak metamorphism; pink: granitoid magmatism (and Permian volcanism); green: Sn-W-polymetallic mineralization; Eugaliès and Leucamp, post-Variscan hydrothermal overprint; Boden, metamorphic skarn (Burisch et al. 2019b); FG epithermal, Freiberg epithermal vein system (Ostendorf et al. 2019). Age data compiled from Chen et al. 1993; Chesley et al. 1993; Moscati and Neymark 2020; Neymark et al. 2018; Shail and Leveridge 2009; Warr et al. 1991 (Cornwall); Alexandrov et al. 2000; Alexandrov et al. 2002; Bertrand et al. 2001; Cheilletz et al. 1992; Cuney et al. 2002; Gebauer et al. 1981; Harlaux et al. 2018; Le Carlier de Veslud et al. 2013; Melleton et al. 2015; Scaillet et al. 1996 (French Massif Central); Carocci 2019; Chicharro et al. 2014; Chicharro et al. 2016; Dias et al. 1998; Díaz Alvarado et al. 2013; Escuder Viruete et al. 1998; Gloaguen 2006; Melleton et al. 2015; Moura et al. 2014; Orejana et al. 2012; Priem and Tex 1984; Snee et al. 1988; TimónSánchez et al. 2019; Zhang et al. 2019 (Iberian Massif); Burisch et al. 2019b; Förster 1999; Förster and Romer 2010; Gehmlich et al. 2001; Hoffmann et al. 2013; Hofmann et al. 2009; Hübner et al. 2020; Kováŕíková et al. 2007; Kröner and Willner 1998; Lefebvre et al. 2019; Luthardt et al. 2018; Nasdala et al. 1998; Ostendorf et al. 2019; Quadt 1993; Romer et al. 2007; Romer et al. 2010; Seckendorff et al. 2004; Tichomirowa et al. 2019; Tichomirowa and Leonhardt 2010; Zhang et al. 2017 (Erzgebirge)

a similar age around 295 to $275 \mathrm{Ma}$ (including outliers; Fig. 7; Harlaux et al. 2018; Ostendorf et al. 2019). At least for the Erzgebirge and the Iberian Massif, the youngest ages are supported by late magmatic activity (Fig. 7). Geochronological data related to magmatic-hydrothermal deposits in the internal zones of the Variscides range from $~ 335$ to $295 \mathrm{Ma}$ (excluding outliers, see Fig. 7), suggesting that oreformation occurred episodically within a time interval of at least $40 \mathrm{Ma}$. This argues against some previous models that proposed a temporally restricted occurrence of Variscan magmatic-hydrothermal ore deposits in a narrow time interval of $\leq 15$ Ma related to late- and post-collisional magmatism/volcanism (cf. Bouchot et al. 2005; Cuney et al. 2002; Lefebvre et al. 2019; Romer et al. 2007; Zhang et al. 2017).

The almost identical time span in which episodic Sn-W-polymetallic ore deposits occur in all internal zones of the European Variscan Belt suggests a broadly similar evolution of the metallogenic system during the Variscan orogenic cycle in central Europe. 
Episodic ore formation is associated with syn- to late-collisional, late-collisional, and post-collisional magmatism and/or volcanism.

In contrast to the internal zones, the onset of magmatichydrothermal activity in the external Variscan zones (i.e., Cornwall) occurred significantly later at $\sim 295$ to $274 \mathrm{Ma}$ (Fig. 7) and appears to have a shorter duration ( $21 \mathrm{Ma}$; Chesley et al. 1993; Moscati and Neymark 2020). The magmatism and associated ore-formation in Cornwall, thus, post-date the peak of regional metamorphism by at least $30 \mathrm{Ma}$ and coincide with the youngest records of magmatic and magmatic-hydrothermal activity in the internal zones of the European Variscan Belt at 295 to 275 Ma.

\section{Conclusions}

Uranium-Pb LA-ICP-MS garnet ages from the Schwarzenberg District suggest that magmatic-hydrothermal skarn formation in the Erzgebirge occurred repeatedly and episodically. Skarns with significant ( $\mathrm{W}-$ ) metal endowment may have already formed in the immediate aftermath of peak metamorphism. Polyphase skarns, particularly those which are affected by late- and postcollisional hydrothermal overprinting, represent the most promising exploration targets in the Schwarzenberg District, since they tend to be large and exceptionally well-endowed (this study; Anglo Saxony Mining Ltd. 2020; Bauer et al. 2019a; Burisch et al. 2019b; Schuppan and Hiller 2012). From the results obtained in the Schwarzenberg District, the presence of laterally consistent (meta-) carbonate units appears to be a more important constraint for exploration for such skarn deposits in the Erzgebirge than the proximity of a known granite intrusion of a particular age or geotectonic position.

Reasons for the congruent magmatic-hydrothermal evolution that connects all the internal zones of the Variscan Orogenic Belt across central and western Europe - and the distinct later occurrence (by approximately $30 \mathrm{Ma}$ ) of magmatic-hydrothermal ore deposits in the external zones of the European Variscan Belt - will demand an explanation at the continental scale. We tentatively propose that the distinct difference may be related to the relative position and distance of each zone to the Variscan collisional front. In analogy to the time-space relationships documented for major porphyry-Cu belts of South America (Sillitoe and Perelló 2005), the timing of ore formation in the Variscan Sn-W provinces may be interpreted as a function of their tectonic position relative to the Rheic suture (Romer and Kroner 2015).

Supplementary Information The online version contains supplementary material available at https://doi.org/10.1007/s00126-021-01084-x.

Acknowledgements We thank Nils Jansson, Deng Xiao-Dong, and Julien Mercadier for their constructive reviews which helped to improve an earlier version of this manuscript and Julien Mercadier for the editorial handling. We thank A. Hiller, M. Slomke (Wismut
GmbH), M. Lapp, and J. Richter (Bohrkernarchiv Sächsisches Landesamt für Umwelt, Landwirtschaft und Geologie) for providing access to sample material, drill-cores, and legacy data. We are grateful to $\mathrm{C}$. Kehrer for access to the geoscientific collection of the TU Bergakademie Freiberg as well as A. Bartzsch, R. Würkert, and M. Stoll for sample preparation at the Helmholtz Institute Freiberg for Resource Technology. S. Gilbricht assisted with SEM data collection. FIERCE is financially supported by the Wilhelm and Else Heraeus Foundation and by the Deutsche Forschungsgemeinschaft (DFG, INST 161/921-1 FUGG and INST 161/923-1 FUGG), which is gratefully acknowledged. This is FIERCE contribution No. 80.

Funding Open Access funding enabled and organized by Projekt DEAL. This study was funded by the Federal State of Saxony and the European Social Fund (Grant no. 100339454 received by M. Burisch).

Open Access This article is licensed under a Creative Commons Attribution 4.0 International License, which permits use, sharing, adaptation, distribution and reproduction in any medium or format, as long as you give appropriate credit to the original author(s) and the source, provide a link to the Creative Commons licence, and indicate if changes were made. The images or other third party material in this article are included in the article's Creative Commons licence, unless indicated otherwise in a credit line to the material. If material is not included in the article's Creative Commons licence and your intended use is not permitted by statutory regulation or exceeds the permitted use, you will need to obtain permission directly from the copyright holder. To view a copy of this licence, visit http://creativecommons.org/licenses/by/4.0/.

\section{References}

Alexandrov P, Cheilletz A, Deloule É, Cuney M (2000) $319 \pm 7$ Ma crystallization age for the Blond granite (northwest Limousin, French Massif Central) obtained by $\mathrm{U} / \mathrm{Pb}$ ion-probe dating of zircons. C R Acad Sci Ser IIA Earth Planet Sci 330:617-622. https:// doi.org/10.1016/S1251-8050(00)00201-9

Alexandrov P, Ruffet G, Cheilletz A (2002) Muscovite recrystallization and saddle-shaped $40 \mathrm{Ar} / 39 \mathrm{Ar}$ age spectra: example from the Blond granite (Massif Central, France). Geochim Cosmochim Acta 66:1793-1807. https://doi.org/10.1016/S0016-7037(01) 00895-X

Anglo Saxony Mining Ltd. (2020) Tellerhäuser Project. http://www. anglosaxony.com/tellerhaeuser-project/. Accessed 5 February 2020

Bauer ME, Seifert T, Burisch M, Krause J, Richter N, Gutzmer J (2019a) Indium-bearing sulfides from the Hämmerlein skarn deposit, Erzgebirge, Germany: evidence for late-stage diffusion of indium into sphalerite. Miner Deposita 54:175-192. https:// doi.org/10.1007/s00126-017-0773-1

Bauer ME, Burisch M, Ostendorf J, Krause J, Frenzel M, Seifert T, Gutzmer J (2019b) Trace element geochemistry of sphalerite in contrasting hydrothermal fluid systems of the Freiberg district, Germany: insights from LA-ICP-MS analysis, near-infrared light microthermometry of sphalerite-hosted fluid inclusions, and sulfur isotope geochemistry. Miner Deposita 54:237-262. https://doi. org/10.1007/s00126-018-0850-0

Bertrand JM, Leterrier J, Cuney M, Brouand M, Stussi JM, Delaperrière E, Virlogeux D (2001) Géochronologie U-Pb sur zircons de granitoïdes du Confolentais, du massif de Charroux-Civray (seuil du Poitou) et de Vendée*: Zircon U-Pb geochronology of granitoids from Confolentais, the Charroux-Civray massif (seuil du Poitou) and Vendée. Géologie de la France:167-189 
Bouchot V, Ledru P, Lerouge C, Lescuyer J-L, Milesi J-P (2005) 5: Late Variscan mineralizing systems related to orogenic processes: the French Massif Central. Ore Geol Rev 27:169-197. https://doi. org/10.1016/j.oregeorev.2005.07.017

Burisch M, Gerdes A, Walter BF, Neumann U, Fettel M, Markl G (2017) Methane and the origin of five-element veins: mineralogy, age, fluid inclusion chemistry and ore forming processes in the Odenwald, SW Germany. Ore Geol Rev 81:42-61. https://doi.org/ 10.1016/j.oregeorev.2016.10.033

Burisch M, Walter BF, Gerdes A, Lanz M, Markl G (2018) Late-stage anhydrite-gypsum-siderite-dolomite-calcite assemblages record the transition from a deep to a shallow hydrothermal system in the Schwarzwald mining district, SW Germany. Geochim Cosmochim Acta 223:259-278. https://doi.org/10.1016/j.gca.2017.12.002

Burisch M, Hartmann A, Bach W, Krolop P, Krause J, Gutzmer J (2019a) Genesis of hydrothermal silver-antimony-sulfide veins of the Bräunsdorf sector as part of the classic Freiberg silver mining district, Germany. Miner Deposita 54:263-280https://doi.org/ 10.1007/s00126-018-0842-0

Burisch M, Gerdes A, Meinert LD, Albert R, Seifert T, Gutzmer J (2019b) The essence of time - fertile skarn formation in the Variscan Orogenic Belt. Earth Planet Sci Lett 519:165-170. https:// doi.org/10.1016/j.eps1.2019.05.015

Carocci E (2019) Tungsten transport and deposition in magmatichydrothermal environments: the example of Panasqueira (Portugal), Doctoral Thesis, Earth Sciences, Université de Lorraine, English. NNT:2019LORR0315

Cheilletz A, Cuney M, Charoy B, Farrar E, Archibald DA (1992) 40 $\mathrm{Ar} / 39 \mathrm{Ar}$ ages of the Beauvoir topaze-lepidolite leucogranite and the Chedeville sodolithic pegmatite (North French Massif Central) petrologic and geodynamic signification. Comptes Rendus De L'academie Des Sciences Serie 2(315):329-336

Chen Y, Clark AH, Farrar E, Wasteneys H, Hodgson MJ, Bromley AV (1993) Diachronous and independent histories of plutonism and mineralization in the Cornubian Batholith, southwest England. J Geol Soc 150:1183-1191. https://doi.org/10.1144/gsjgs.150.6. 1183

Chesley JT, Halliday AN, Snee LW, Mezger K, Shepherd TJ, Scrivener RC (1993) Thermochronology of the Cornubian batholith in southwest England: implications for pluton emplacement and protracted hydrothermal mineralization. Geochim Cosmochim Acta 57:1817-1835. https://doi.org/10.1016/0016-7037(93)90115-D

Chicharro E, Villaseca C, Valverde-Vaquero P, Belousova E, LópezGarcía JÁ (2014) Zircon U-Pb and Hf isotopic constraints on the genesis of a post-kinematic S-type Variscan tin granite: the Logrosán cupola (Central Iberian Zone). Journal of Iberian Geology 40:451-470. https://doi.org/10.5209/rev_JIGE.2014.v40.n3. 43928

Chicharro E, Boiron M-C, López-García JÁ, Barfod DN, Villaseca C (2016) Origin, ore forming fluid evolution and timing of the Logrosán Sn-(W) ore deposits (Central Iberian Zone, Spain). Ore Geol Rev 72:896-913. https://doi.org/10.1016/j.oregeorev.2015. 09.020

Cuney M, Alexandrov P, Carlier Le, de Veslud C, Cheilletz A, Raimbault L, Ruffet G, Scaillet S (2002) The timing of W-Sn-rare metals mineral deposit formation in the Western Variscan chain in their orogenic setting: the case of the Limousin area (Massif Central, France). Geol Soc Lond Spec Publ 204:213-228. https:// doi.org/10.1144/GSL.SP.2002.204.01.13

Dallmeyer RD, Catalán J, Arenas R, Gil Ibarguchi JI, Gutiérrez Alonso G, Farias P, Bastida F, Aller J (1997) Diachronous Variscan tectonothermal activity in the NW Iberian Massif: evidence from 40Ar/39Ar dating of regional fabrics. Tectonophysics 277:307337. https://doi.org/10.1016/S0040-1951(97)00035-8

Deng X-D, Li J-W, Luo T, Wang H-Q (2017) Dating magmatic and hydrothermal processes using andradite-rich garnet $\mathrm{U}-\mathrm{Pb}$ geochronometry. Contrib Mineral Petrol 172:71. https://doi.org/ 10.1007/s00410-017-1389-2

Dias G, Leterrier J, Mendes A, Simões PP, Bertrand JM (1998) U-Pb zircon and monazite geochronology of post-collisional Hercynian granitoids from the Central Iberian Zone (Northern Portugal). Lithos 45:349-369. https://doi.org/10.1016/S0024-4937(98) 00039-5

Dias G, Simões PP, Ferreira N, Leterrier J (2002) Mantle and crustal sources in the Genesis of late-Hercynian granitoids (NW Portugal): geochemical and $\mathrm{Sr}-\mathrm{Nd}$ isotopic constraints. Gondwana Res 5:287-305. https://doi.org/10.1016/S1342-937X(05)70724-3

Díaz Alvarado J, Fernández C, Castro A, Moreno-Ventas I (2013) SHRIMP U-Pb zircon geochronology and thermal modeling of multilayer granitoid intrusions. Lithos 175-176:104-123. https:// doi.org/10.1016/j.lithos.2013.05.006

Elsner H (2014) Zinn - Angebot und Nachfrage bis 2020, 2014th edn. DERA Rohstoffinformationen, vol 20. DERA, Berlin

Escuder Viruete J, Hernáiz Huerta P, Valverde-Vaquero P, Rodríguez Fernández R, Dunning G (1998) Variscan syncollisional extension in the Iberian Massif: structural, metamorphic and geochronological evidence from the Somosierra sector of the Sierra de Guadarrama (Central Iberian Zone, Spain). Tectonophysics 290:87-109. https://doi.org/10.1016/S0040-1951(98)00014-6

Faure M, Lardeaux J-M, Ledru P (2009) A review of the pre-Permian geology of the Variscan French Massif Central. CR Geosci 341:202-213. https://doi.org/10.1016/j.crte.2008.12.001

Finger F, Roberts MP, Haunschmid B, Schermaier A, Steyrer HP (1997) Variscan granitoids of central Europe: their typology, potential sources and tectonothermal relations. Miner Petrol 61:67-96. https://doi.org/10.1007/BF01172478

Förster H-J (1999) The chemical composition of uraninite in Variscan granites of the Erzgebirge, Germany. Mineral Mag 63:239-252. https://doi.org/10.1180/002646199548466

Förster H-J, Tischendorf G, Trumbull RB, Gottesmann B (1999) Latecollisional Granites in the Variscan Erzgebirge, Germany. J Petrol 40:1613-1645. https://doi.org/10.1093/petroj/40.11.1613

Förster H-J, Romer RL (2010) Carboniferous magmatism. In: Linnemann U, Romer RL (eds) Pre-Mesozoic geology of Saxo-Thuringia: from the Cadomian active margin to the Variscan orogen. Schweizerbart, Stuttgart, pp 287-308

Gärtner J (2019) Qualitative characterisation of skarn-related metasomatism of the Tafelgneis unit at Hämmerlein occurrence, Germany. Master Thesis, Technische Universität Bergakademie Freiberg

Gebauer D, Bernard-Griffiths J, Grnenfelder M (1981) U-Pb zircon and monazite dating of a mafic-ultramafic complex and its country rocks. Contrib Mineral Petrol 76:292-300. https://doi.org/10. 1007/BF00375456

Gehmlich M, Linnemann U, Tichomirowa M, Gaitzsch B, Bombach K (2001) Geochronology of late Devonian to lower Carboniferous igneous rocks of Thuringian and Bavarian facies, Variscan crustal stacks and the early Variscan Molasse (Hainichen Basin) (SaxoThuringian Terrane). Z Dt Geol Ges 151:337-363. https://doi.org/ $10.1127 / \mathrm{zdgg} / 151 / 2001 / 337$

GeoSN (2020) dl-de/by-2-0. https://geoportal.sachsen.de/. Accessed 25 February 2021

Gerdes A, Zeh A (2006) Combined U-Pb and Hf isotope LA-(MC-) ICP-MS analyses of detrital zircons: Comparison with SHRIMP and new constraints for the provenance and age of an Armorican metasediment in Central Germany. Earth Planet Sci Lett 249:4761. https://doi.org/10.1016/j.eps1.2006.06.039

Gerdes A, Zeh A (2009) Zircon formation versus zircon alteration new insights from combined $\mathrm{U}-\mathrm{Pb}$ and $\mathrm{Lu}-\mathrm{Hf}$ in-situ LA-ICPMS analyses, and consequences for the interpretation of Archean zircon from the central zone of the Limpopo Belt. Chem Geol 261:230-243. https://doi.org/10.1016/j.chemgeo.2008.03.005 
Gevedon M, Seman S, Barnes JD, Lackey JS, Stockli DF (2018) Unraveling histories of hydrothermal systems via $\mathrm{U}-\mathrm{Pb}$ laser ablation dating of skarn garnet. Earth Planet Sci Lett 498:237246. https://doi.org/10.1016/j.epsl.2018.06.036

Gloaguen E (2006) Contribution of an integrated study to the relationships between vein-type deposits ( $\mathrm{Au}$ and $\mathrm{Sn}-\mathrm{W})$ in late orogenic settings. (Hercynian belt, central Galicia, Spain), Université d'Orléans

Guo X, Navrotsky A, Kukkadapu RK, Engelhard MH, Lanzirotti A, Newville M, Ilton ES, Sutton SR, Xu H (2016) Structure and thermodynamics of uranium-containing iron garnets. Geochim Cosmochim Acta 189:269-281. https://doi.org/10.1016/j.gca. 2016.05.043

Harlaux M, Romer RL, Mercadier J, Morlot C, Marignac C, Cuney M (2018) $40 \mathrm{Ma}$ of hydrothermal W mineralization during the Variscan orogenic evolution of the French Massif Central revealed by U-Pb dating of wolframite. Miner Deposita 53:2151. https://doi.org/10.1007/s00126-017-0721-0

Hoffmann U, Breitkreuz C, Breiter K, Sergeev S, Stanek K, Tichomirowa M (2013) Carboniferous-Permian volcanic evolution in central Europe- $-\mathrm{U} / \mathrm{Pb}$ ages of volcanic rocks in Saxony (Germany) and northern Bohemia (Czech Republic). Int J Earth Sci 102:73-99. https://doi.org/10.1007/s00531-012-0791-2

Hofmann M, Linnemann U, Gerdes A, Ullrich B, Schauer M (2009) Timing of dextral strike-slip processes and basement exhumation in the Elbe Zone (Saxo-Thuringian Zone): the final pulse of the Variscan Orogeny in the Bohemian Massif constrained by LA-SF-ICP-MS U-Pb zircon data. Geol Soc Lond Spec Publ 327:197-214. https://doi.org/10.1144/SP327.10

Hong W, Cooke DR, Huston DL, Maas R, Meffre S, Thompson J, Zhang L, Fox N (2017) Geochronological, geochemical and Pb isotopic compositions of Tasmanian granites (southeast Australia): controls on petrogenesis, geodynamic evolution and tin mineralisation. Gondwana Res 46:124-140. https://doi.org/10. 1016/j.gr.2017.03.009

Hösel G (ed) (1994) Das Zinnerz-Lagerstättengebiet Ehrenfriedersdorf, Erzgebirge. Bergbau in Sachsen Bergbaumonographie, vol 1. Landesvermessungsamt Sachsen, Dresden

Hösel G (2003) Die polymetallische Skarnlagerstätte Pöhla-Globenstein, 1st edn. Sächsische Druck- und Verlagshaus AG, Dresden

Hösel G, Haake R (1965) Ergebnisbericht Sucharbeiten Skarn Schwarzenberg 1961-1964 (B-Vorhaben). VEB Geologische Erkundung Süd, Freiberg

Hoth K, Krutský N, Schilka W, Schellenberg F (2010) Marmore im Erzgebirge, 1st edn. Sächsisches Landesamt für Umwelt, Landwirtschaft und Geologie, Freiberg

Hübner M, Repstock A, Rommel A, Fischer F, Lapp M, Breitkreuz C, Heuer F (2020) Der Rochlitzer Supervulkan. vulkanosedimentäre Faziesanalyse und Geochemie der permischen Rochlitz-Ignimbrit-Komplexes und seiner distalen Äquivalente. Sächsisches Landesamt für Umwelt, Landwirtschaft und Geologie (LfULG), Dresden

Kern M, Kästner J, Tolosana-Delgado R, Jeske T, Gutzmer J (2019) The inherent link between ore formation and geometallurgy as documented by complex tin mineralization at the Hämmerlein deposit (Erzgebirge, Germany). Miner Deposita 54:683-698. https://doi.org/10.1007/s00126-018-0832-2

Korges M, Weis P, Lüders V, Laurent O (2019) Sequential evolution of Sn-Zn-In mineralization at the skarn-hosted Hämmerlein deposit, Erzgebirge, Germany, from fluid inclusions in ore and gangue minerals. Miner Deposita. https://doi.org/10.1007/ s00126-019-00905-4

Kovář́íková P, Siebel W, Jelínek E, Štemprok M, Kachlík V, Holub FV, Blecha V (2007) Petrology, geochemistry and zircon age for redwitzite at Abertamy, NW Bohemian Massif (Czech Republic): tracing the mantle component in Late Variscan intrusions.
Geochemistry 67:151-174. https://doi.org/10.1016/j.chemer.2007. 04.002

Kozlik M, Raith JG, Gerdes A (2016) U-Pb, Lu-Hf and trace element characteristics of zircon from the Felbertal scheelite deposit (Austria): new constraints on timing and source of $\mathrm{W}$ mineralization. Chem Geol 421:112-126. https://doi.org/10.1016/j.chemg eo.2015.11.018

Kroner U, Mansy J-L, Mazur S, Aleksandrowski P, Hann HP, Huckriede $\mathrm{H}$, Lacquement $\mathrm{F}$, Lamarche J, Ledru $\mathrm{P}$, Pharaoh TC, Zedler H, Zeh A, Zulauf G (2008) Variscan tectonics. In: McCann T (ed) The Geology of Central Europe Volume 1: Precambrian and Palaeozoic. The Geological Society of London, London, pp 599-664

Kroner U, Romer RL (2013) Two plates - Many subduction zones: the Variscan orogeny reconsidered. Gondwana Res 24:298-329. https://doi.org/10.1016/j.gr.2013.03.001

Kröner A, Willner AP (1998) Time of formation and peak of Variscan HP-HT metamorphism of quartz-feldspar rocks in the central Erzgebirge, Saxony, Germany. Contrib Mineral Petrol 132:1-20. https://doi.org/10.1007/s004100050401

Carlier Le, de Veslud C, Alexandre P, Ruffet G, Cuney M, Cheilletz A (2013) A two-stage exhumation in Western French Massif Central: new geochronological evidences of syn-collisional extension. Lithos 175-176:1-15. https://doi.org/10.1016/j.lithos.2013.04.013

Lefebvre MG, Romer RL, Glodny J, Kroner U, Roscher M (2019) The Hämmerlein skarn-hosted polymetallic deposit and the Eibenstock granite associated greisen, western Erzgebirge, Germany: two phases of mineralization-two Sn sources. Miner Deposita 54:193-216. https://doi.org/10.1007/s00126-018-0830-4

Lehmann B (2020) Formation of tin ore deposits: a reassessment. Lithos 402-403:105756. https://doi.org/10.1016/j.lithos.2020. 105756

Lorenz W, Hoth K (1967) Räumliche Gesetzmäßigkeiten der Skarnverbreitung im Erzgebirge (Geologische Fragen der Skarnprognose im Erzgebirge - Teil 2). Geologie 16:1007-1030

Luthardt L, Hofmann M, Linnemann U, Gerdes A, Marko L, Rößler R (2018) A new U-Pb zircon age and a volcanogenic model for the early Permian Chemnitz fossil forest. Int J Earth Sci 107:24652489. https://doi.org/10.1007/s00531-018-1608-8

Meinert LD, Dipple GM, Nicolescu S (2005) World Skarn Deposits. In: Hedenquist JW (ed) Economic geology: 100th anniversary volume 1905-2005. Society of Economic Geologists, Littleton

Melleton J, Gloaguen E, Frei D (2015) Rare-Elements (Li-Be-Ta-Sn$\mathrm{Nb})$ Magmatism in the European Variscan Belt, a review. In: André-Mayer A-S, Cathlineau M, Muchez P, Pirard E, Sindern S (eds) Mineral resources in a sustainable world. Proceedings of the 13th Biennial SGA Meeting, vol 2. Society for Geology Applied to Mineral Deposits, Nancy, pp 807-810

Meyer H, Röthig H (1967) Bericht zur Kartierung der Grube "Herkules Frisch Glück" bei Waschleithe (Erzgebirge). VEB Geologische Erkundung Süd, Freiberg

Millonig LJ, Gerdes A, Groat LA (2012) U-Th-Pb geochronology of meta-carbonatites and meta-alkaline rocks in the southern Canadian Cordillera: a geodynamic perspective. Lithos 152:202-217. https://doi.org/10.1016/j.lithos.2012.06.016

Moscati RJ, Neymark LA (2020) U-Pb geochronology of tin deposits associated with the Cornubian Batholith of southwest England: direct dating of cassiterite by in situ LA-ICPMS. Miner Deposita 55:1-20. https://doi.org/10.1007/s00126-019-00870-y

Moura A, Dória A, Neiva A, Leal Gomes C, Creaser RA (2014) Metallogenesis at the Carris W-Mo-Sn deposit (Gerês, Portugal): constraints from fluid inclusions, mineral geochemistry, Re-Os and $\mathrm{He}-\mathrm{Ar}$ isotopes. Ore Geol Rev 56:73-93. https://doi.org/10. 1016/j.oregeorev.2013.08.001

Nasdala L, Pidgeon RT, Wolf D, Irmer G (1998) Metamictization and U-PB isotopic discordance in single zircons: a combined Raman 
microprobe and SHRIMP ion probe study. Miner Petrol 62:1-27. https://doi.org/10.1007/BF01173760

Neymark LA, Holm-Denoma CS, Moscati RJ (2018) In situ LAICPMS U-Pb dating of cassiterite without a known-age matrixmatched reference material: examples from worldwide tin deposits spanning the Proterozoic to the Tertiary. Chem Geol 483:410-425. https://doi.org/10.1016/j.chemgeo.2018.03.008

Orejana D, Villaseca C, Valverde-Vaquero P, Belousova EA, Armstrong RA (2012) U-Pb geochronology and zircon composition of late Variscan S- and I-type granitoids from the Spanish central system batholith. Int J Earth Sci 101:1789-1815. https:// doi.org/10.1007/s00531-012-0750-y

Ostendorf J, Henjes-Kunst F, Seifert T, Gutzmer J (2019) Age and genesis of polymetallic veins in the Freiberg district, Erzgebirge, Germany: constraints from radiogenic isotopes. Miner Deposita 54:217-236. https://doi.org/10.1007/s00126-018-0841-1

Priem HN, den Tex E (1984) Tracing crustal evolution in the NW Iberian Peninsula through the R-Sr and U-Pb systematics of Palaeozoic granitoids: a review. Phys Earth Planet Inter 35:121130. https://doi.org/10.1016/0031-9201(84)90038-4

von Quadt A (1993) The Saxonian Granulite Massif: new aspects from geochronological studies. Geol Rundsch 82:516-530. https://doi.org/10.1007/BF00212414

Rák Z, Ewing RC, Becker U (2011) Role of iron in the incorporation of uranium in ferric garnet matrices. Phys Rev B 84:155128. https://doi.org/10.1103/PhysRevB.84.155128

Reinhardt N, Frenzel M, Meinert LD, Gutzmer J, Kürschner T, Burisch M (2021) Mineralogy and fluid characteristics of the Waschleithe Zn skarn - a distal part of the Schwarzenberg mineral system, Erzgebirge, Germany. Ore Geol Rev 131:104007. https://doi.org/10.1016/j.oregeorev.2021.104007

Richards JP (2011) Magmatic to hydrothermal metal fluxes in convergent and collided margins. Ore Geol Rev 40:1-26. https:// doi.org/10.1016/j.oregeorev.2011.05.006

Roberts NMW, Drost K, Horstwood MSA, Condon DJ, Chew D, Drake H, Milodowski AE, McLean NM, Smye AJ, Walker RJ, Haslam R, Hodson K, Imber J, Beaudoin N, Lee JK (2020) Laser ablation inductively coupled plasma mass spectrometry (LA-ICP-MS) U-Pb carbonate geochronology: strategies, progress, and limitations. Geochronology 2:33-61. https://doi.org/ 10.5194/gchron-2-33-2020

Romer RL, Kroner U (2015) Sediment and weathering control on the distribution of Paleozoic magmatic tin-tungsten mineralization. Miner Deposita 50:327-338. https://doi.org/10.1007/ s00126-014-0540-5

Romer RL, Kroner U (2016) Phanerozoic tin and tungsten mineralization-tectonic controls on the distribution of enriched protoliths and heat sources for crustal melting. Gondwana Res 31:60-95. https://doi.org/10.1016/j.gr.2015.11.002

Romer RL, Thomas R, Stein HJ, Rhede D (2007) Dating multiply overprinted Sn-mineralized granites - examples from the Erzgebirge, Germany. Miner Deposita 42:337-359. https://doi.org/10. 1007/s00126-006-0114-2

Romer RL, Förster H-J, Štemprok M (2010) Age constraints for the late-Variscan magmatism in the Altenberg-Teplice Caldera (Eastern Erzgebirge/Krušné hory). N Jb Mineral Abh 187:289305. https://doi.org/10.1127/0077-7757/2010/0179

Scaillet S, Cheilletz A, Cuney M, Farrar E, Archibald DA (1996) Cooling pattern and mineralization history of the Saint Sylvestre and western Marche leucogranite pluton, French Massif Central: I. 40Ar/39Ar isotopic constraints. Geochim Cosmochim Acta 60:4653-4671. https://doi.org/10.1016/S0016-7037(96)00291-8

Schmädicke E, Mezger K, Cosca MA, Okrusch M (1995) Variscan Sm-Nd and Ar-Ar ages of eclogite facies rocks from the Erzgebirge, Bohemian Massif. J Metamorph Geol 13:537-552. https://doi.org/10.1111/j.1525-1314.1995.tb00241.x

Schuppan W, Hiller A (2012) Die Komplexlagerstätten Tellerhäuser und Hämmerlein, 1st edn. Sächsisches Landesamt für Umwelt, Landwirtschaft und Geologie, Freiberg

von Seckendorff V, Timmerman MJ, Kramer W, Wrobel P (2004) New $40 \mathrm{Ar} / 39 \mathrm{Ar}$ ages and geochemistry of late Carboniferous-early Permian lamprophyres and related volcanic rocks in the Saxothuringian Zone of the Variscan Orogen (Germany). Geol Soc Lond Spec Publ 223:335-359. https://doi.org/10.1144/GSL.SP. 2004.223.01.15

Seman S, Stockli DF, McLean NM (2017) U-Pb geochronology of grossular-andradite garnet. Chem Geol 460:106-116. https://doi. org/10.1016/j.chemgeo.2017.04.020

Shail RK, Leveridge BE (2009) The Rhenohercynian passive margin of SW England: development, inversion and extensional reactivation. CR Geosci 341:140-155. https://doi.org/10.1016/j.crte. 2008.11.002

Sillitoe RH, Perelló J (2005) Andean copper provincetectonomagmatic settings, deposit types, metallogeny, exploration, and discovery. In: Hedenquist JW (ed) Economic geology: 100th anniversary volume 1905-2005. Society of Economic Geologists, Littleton

Smith MP, Henderson P, Jeffries T, Long J, Williams CT (2004) The rare earth elements and uranium in garnets from the Beinn an Dubhaich Aureole, Skye, Scotland, UK: Constraints on Processes in a Dynamic Hydrothermal System. J Petrol 45:457-484. https:// doi.org/10.1093/petrology/egg087

Snee LW, Sutter JF, Kelly WC (1988) Thermochronology of economic mineral deposits; dating the stages of mineralization at Panasqueira, Portugal, by high-precision 40 / 39 Ar age spectrum techniques on muscovite. Econ Geol 83:335-354. https://doi.org/ 10.2113/gsecongeo.83.2.335

Swinkels L, Schulz-Isenbeck J, Frenzel M, Gutzmer J, Burisch M (2021) Spatial and Temporal Evolution of the Freiberg Epithermal Ag-Pb-Zn District, Germany. Econ Geol 116:1649-1667.https:// doi.org/10.5382/econgeo.4833

Tera F, Wasserburg GJ (1972) U-Th-Pb systematics in three Apollo 14 basalts and the problem of initial $\mathrm{Pb}$ in lunar rocks. Earth Planet Sci Lett 14:281-304. https://doi.org/10.1016/0012-821X(72) 90128-8

Tichomirowa M, Leonhardt $\mathrm{D}$ (2010) New age determinations $(\mathrm{Pb} / \mathrm{Pb}$ zircon evaporation, $\mathrm{Rb} / \mathrm{Sr}$ ) on the granites from Aue-Schwarzenberg and Eibenstock, Western Erzgebirge, Germany. Z Geol Wiss 38:99-123

Tichomirowa M, Käßner A, Sperner B, Lapp M, Leonhardt D, Linnemann U, Münker C, Ovtcharova M, Pfänder JA, Schaltegger U, Sergeev S, von Quadt A, Whitehouse M (2019) Dating multiply overprinted granites: the effect of protracted magmatism and fluid flow on dating systems (zircon U-Pb: SHRIMP/SIMS, LAICP-MS, CA-ID-TIMS; and Rb-Sr, Ar-Ar) - Granites from the Western Erzgebirge (Bohemian Massif, Germany). Chem Geol 519:11-38. https://doi.org/10.1016/j.chemgeo.2019.04.024

Timón-Sánchez SM, López-Moro FJ, Romer RL, Rhede D, FernándezFernández A, Moro-Benito C (2019) Late-Variscan multistage 
hydrothermal processes unveiled by chemical ages coupled with compositiona. GACTA. https://doi.org/10.1344/GeologicaActa20 19.17.1

Wafforn S, Seman S, Kyle JR, Stockli D, Leys C, Sonbait D, Cloos M (2018) Andradite Garnet U-Pb geochronology of the Big Gossan Skarn, Ertsberg-Grasberg Mining District, Indonesia. Econ Geol 113:769-778. https://doi.org/10.5382/econgeo.2018.4569

Warr LN, Primmer TJ, Robinson D (1991) Variscan very low-grade metamorphism in southwest England: a diastathermal and thrustrelated origin. J Metamorph Geol 9:751-764. https://doi.org/10. 1111/j.1525-1314.1991.tb00563.x

Yuan S, Peng J, Hao S, Li H, Geng J, Zhang D (2011) In situ LAMC-ICP-MS and ID-TIMS U-Pb geochronology of cassiterite in the giant Furong tin deposit, Hunan Province, South China: new constraints on the timing of tin-polymetallic mineralization. Ore Geol Rev 43:235-242. https://doi.org/10.1016/j.oregeorev.2011. 08.002

Zhang R, Lehmann B, Seltmann R, Sun W, Li C (2017) Cassiterite $\mathrm{U}-\mathrm{Pb}$ geochronology constrains magmatic-hydrothermal evolution in complex evolved granite systems: the classic Erzgebirge tin province (Saxony and Bohemia). Geology 45:1095-1098. https:// doi.org/10.1130/G39634.1

Zhang R, Ramos V, Leal S, Noronha F, Pinto Filipe (2019) U-Pb geochronology of cassiterites from primary $\mathrm{Sn}$ mineralizations in Sn-W Variscan Metallogenic Province, Portugal. Proceedings of the 15th SGA Biennial Meeting 27-30 August 2019:357-360

Publisher's note Springer Nature remains neutral with regard to jurisdictional claims in published maps and institutional affiliations. 